\title{
Distinct Neurochemical Populations in the Rat Central Nucleus of the Amygdala and Bed Nucleus of the Stria Terminalis: E vidence for Their Selective Activation by Interleukin-1及
}

\author{
HEIDI E.W. DAY,1* EILEEN J . CURRAN,2 STANLEY J . WATSON, J R.,1 \\ AND HUDA AKIL ${ }^{1}$ \\ 1Mental Health Research I nstitute, University of Michigan, Ann Arbor, Michigan 48109 \\ ${ }^{2}$ Amgen, I nc., Thousand Oaks, California 91320
}

\begin{abstract}
The lateral division of the central nudeus of the amygdala (CEAI) and the oval nucleus of the bed nucleus of the stria terminalis (BSTov) have been linked dosely anatomically and functionally. To determine whether these regions may be subdivided further on a neurochemical basis, dual in situ hybridization was used to determine the colocalization of corticotropinreleasing hormone $(\mathrm{CRH})$, enkephalin $(\mathrm{ENK})$, or neurotensin (NT) with glutamic acid decarboxylase isoforms 65 and 67 [used concurrently as a marker for $\gamma$-aminobutyric acid GABA] in these nuclei. It was found that, for both regions, each peptide invariably was localized in a GABAergic cell. Although there was a similar overlap in the distribution of NT with ENK in the BSTov and CEAl, it was observed that $\mathrm{CRH}$ and ENK rarely were colocalized in either nucleus. To determine whether these distinct neuronal populations could be activated differentially, male rats were given a systemic injection of interleukin-1 $(\mathrm{IL}-1 \beta ; 5$ $\mu \mathrm{g} / \mathrm{kg}$, i.p. ), a stimulus that results in a robust increase in c-fos mRNA expression in the BSTov and CEAl. The neurochemical identity of these activated neurons showed striking similarities between the BSTov and the CEAI; All I L-1 $\beta$-responsive cells were GABAergic, the majority of c-fos- positive cells expressed ENK mRNA (BSTov, 81\%; CEAI, 94\%), and some expressed NT mRNA (BSTov, 23\%; CEAI, 22\%), whereas very few expressed CRH mRNA (BSTov, 4\%; CEAI, 1\%). These data provide evidence for the existence of discrete neural circuits within the BSTov and CEAl, and the similarities in the patterns of neurochemical colocalization in these nuclei are consistent with the concept of an extended amygdala. F urthermore, these data indicate that intraperitoneal I L-1 $\beta$ recruits neurochemically distinct pathways within the BSTov and $\mathrm{CEAl}$, and it is suggested that this differential activation may mediate specific aspects of immune, limbic, and/or autonomic processes. J . Comp. Neurol . 413:113-128, 1999.
\end{abstract}

(๑) 1999 Wiley-Liss, Inc.

Indexing terms: corticotropin-releasing hormone; enkephalin; neurotensin; $\gamma$-aminobutyric acid; c-fos

A significant body of work has demonstrated both anatomical and functional similarities between the lateral division of the central nucleus of the amygdala (CEAI) and the oval nucleus of the bed nucleus of the stria terminalis (BSTov: J u and Swanson, 1989; J u et al., 1989; Swanson 1992; equivalent to the dorsal lateral subnucleus of Moga et al., 1989). I ndeed, together with the substantia inominata, it has been proposed that these structures form the central extended amygdala (for review, Alheid et al., 1995). Although it is not the purpose of this article to review all of the anatomical connections of these nudei, it is worth noting the strong topographic projections from the CEA to the BST (Sun et al., 1991). Furthermore, both structures are connected reciprocally with the parabrachial nucleus

Grant sponsor: NIDA; Grant number: 5RO1 DA02265-18; Grant sponsor: NIMH; Grant number: 2PO1 MH42251-11.

*Correspondence to: Dr. H.E.W. Day, Mental Health Research Institute, 205 Zina Pitcher Place, Ann Arbor, MI 48109-0720.

E-mail: heididay@umich.edu

Received 17 December 1998; Revised 3] une 1999; Accepted 17 J une 1999 
(Moga and Gray, 1985; Moga et al., 1989; Bernard et al., 1993; Krukoff et al., 1993; Alden et al., 1994) and the nudeus tractus solitarius (NTS; Ricardo and Koh, 1978; Gray and Magnuson, 1987), and they share a number of other common efferent and afferent inputs, as outlined in more detail below. Although the functional significance of activation of these regions is not clear, together, they are thought to be involved in the coordination of central autonomic function (Saper, 1995). Furthermore, the BST and CEA have been associated with the elicitation and integration of behavioral and possibly emotional responses to anxiety, fear, and stress (Davis, 1992; Gallagher and Chiba, 1996; Maren and F anselow, 1996).

With such a diverse array of complex functions ascribed to the BST and CEA, it is not surprising that these nuclei receive inputs from a wide variety of sources. For example, cortical areas (Hurley et al., 1991; Sun et al., 1994; McDonald and Mascagni, 1997), thalamic areas (Moga et al., 1995), hypothalamic areas (Cullinan and Zaborsky, 1991; Canteras et al., 1994; Vertes et al., 1995), and brainstem areas (Ricardo and Koh, 1978; Bernard et al., 1993; Krukoff et al., 1993; Alden et al., 1994) as well as other amygdaloid nuclei (Weller and Smith, 1982; Canteras et al., 1995; Savander et al., 1995, 1996) have been shown to project to the BST and the CEA. To achieve functional differentiation, there is a considerable degree of anatomical specificity within the BST and CEA in the targets of these different inputs. F or example, a subset of cortical areas (Sun et al., 1994; McDonald and Mascagni, 1997), thalamic areas (Moga et al., 1995), and brainstem areas (Ricardo and Koh, 1978; Krukoff et al., 1993) project to the CEAI. Within the CEAI, although it appears that inputs from these different origins overlap broadly, one way in which further functional separation may be gained is by targeting distinct neurochemical subpopulations within the nudeus. Although these neurons may be different functionally, because they are in close proximity to one another, their roles may become integrated and coordinated. In addition, if these patterns of segregation appear consistently across other components of the central extended amygdala, then this would lend support to the proposed coherent nature and functional relevance of these areas.

Several studies have been published describing the distribution of various peptides in the BST and the CEA (Wray and Hoffman, 1983; Cassell et al., 1986; J u et al., 1989; Moga et al., 1989; Shimada et al., 1989). Although these studies have demonstrated similarities in the expression of a number of peptides between the BSTov and the CEAl, they also have indicated that, within these subnuclei, there is differential peptide expression. The few colocalization studies that have been published indicate that there may be neurochemically distinct neuronal populations within the BSTov and the CEAI (Oertel et al., 1983; Shimada et al., 1989; Veinante et al., 1997). F urthermore, these two nuclei are known to be highly $\gamma$-aminobutyric acidergic (GABAergic; Sun and Cassell, 1993), and there is some evidence from immunocytochemical studies on adjacent sections to suggest that GABAergic neurons of the BSTov and the CEAl synthesize either corticotropinreleasing hormone $(\mathrm{CRH})$ or enkephalin (ENK; Veinante et al., 1997).

In this study, a double in situ hybridization (ISH) technique was used to extend these findings in experimentally naïve adult male rats. The degree of colocalization of
ENK, neurotensin (NT), or CRH mRNA in GABAergic neurons of the BSTov and the CEAI was determined initially. F urthermore, we determined whether or not $\mathrm{CRH}$ or NT mRNA was expressed in enkephalinergic cells. These studies revealed a highly discrete pattern of peptide colocalization, and we went on to ask whether these neurochemically distinct neuronal populations of theBSTov and CEAI could be activated selectively by an intraperito-

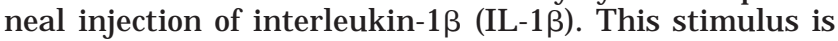
known to elicit c-fos mRNA expression in the BSTov and CEAl (Brady et al., 1994; Day and Akil, 1996), which is thought to reflect synaptic or transcriptional activation. The extent of colocalization of IL-1 $\beta$-induced $c$-fos mRNA in GABAergic neurons and in cells that express ENK, NT, or $\mathrm{CRH}$ mRNA in the BSTov or CEAl was established. Preliminary data from this work were presented previously in abstract form (Day et al., 1996).

\section{MATERIALS AND METHODS Animals}

All animal procedures were approved by University of Michigan Committee on Use and Care of Animals. Male Sprague-Dawley rats (Charles River Laboratories, Wilmington, MA), weighing 250-300 g were used. Rats were housed five or six per cage under conditions of constant temperature and humidity on a 12-hour light/dark cycle (lights on at 0600) with access to food and water ad libitum. Six rats that were naïve to handling or other treatment regimens were used for neurochemical colocalization studies. Animals that received saline $(n=5)$ or IL-1 injections $(n=6)$ were handled daily for 1 week prior tothe experiment.

\section{Administration of IL-1 $\beta$}

IL-1 (human, recombinant) was obtained from Bachem (Torrance, CA). The manufacturer's specifications stated that endotoxin levels were $<0.1 \mathrm{ng}$ per $\mu \mathrm{g}$ of IL-1 $\beta$. The specific activity was approximately $5 \times 10^{7} \mathrm{U} / \mathrm{mg}$ protein. Animals were given an intraperitoneal (i.p.) injection of IL-1,$(5 \mu \mathrm{g} / \mathrm{ml} / \mathrm{kg} ; \mathrm{n}=6)$ or an equivalent volume of $0.9 \%$ sterile, pyrogen-free saline $(n=5)$ and were returned to their home cage. I njections were given 2-3 hours after the onset of the light period.

\section{Tissue preparation}

Animals were rapidly decapitated directly after being removed from the home cage for naïve rats or 30 minutes after injection of I L-1 $\beta$ or saline. Brains were removed and frozen in isopentane cooled to between $-40^{\circ} \mathrm{C}$ and $-50^{\circ} \mathrm{C}$ and were stored at $-80^{\circ} \mathrm{C}$. Sections ( $10 \mu \mathrm{m}$ thick) were cut on a cryostat (Bright, Huntingdon, United Kingdom) through the BST (approximately 0.20 to $-0.80 \mathrm{~mm}$ from Bregma) and CEA (approximately -1.80 to $-3.60 \mathrm{~mm}$ from Bregma) and thaw mounted onto polylysine-coated slides. Tissue was air dried and stored at $-80^{\circ} \mathrm{C}$ until processing for ISH.

\section{Double ISH histochemistry}

The method used for double ISH was adapted from that described by Curran and Watson (1995). The specificity of the probes was confirmed in control experiments by using sense probes or tissue that had been pretreated with RNase $A(200 \mu \mathrm{g} / \mathrm{ml})$ for 1 hour at $37^{\circ} \mathrm{C}$ prior to hybridiza- 
tion with antisense probes. No specific hybridization was observed for any of the controls.

\section{Probes}

cRNA probes complementary to c-fos (680 mer; courtesy of Dr. T. Curran, St. J ude Children's Research Hospital, Memphis, TN), glutamic acid decarboxylase 65 (GAD65; 230 mer; courtesy of Dr. N.J .K. Tillakaratne, University of California), GAD67 (210 mer; courtesy of Dr. A. Tobin, University of California-Los Angeles), ENK (693 mer; courtesy of Dr. J . Douglass, Amgen, Inc., Thousand Oaks, CA), NT (587 mer; courtesy of Dr. P. Dobner, University of Massachusetts), and CRH (770 mer; courtesy of Dr. R. Thompson, U niversity of Michigan) were used.

To generate ${ }^{35} \mathrm{~S}-$ labeled cRNA probes, linearized plasmid $(1 \mu \mathrm{g})$ was incubated at $37^{\circ} \mathrm{C}$ for 2 hours in $1 \times$ transcription buffer (Gibco BRL, Grand I sland, NY), $75 \mu \mathrm{Ci} \alpha-\left[{ }^{35} \mathrm{~S}\right]-$ UTP ( $\geq 1,000 \mathrm{Ci} / \mathrm{mmol} ; 20 \mathrm{mCi} / \mathrm{ml}$; Amersham, Arlington Heights, IL), $100 \mu \mathrm{Ci} \alpha$-[35S]-CTP $(800 \mathrm{Ci} / \mathrm{mmol} ; 40 \mathrm{mCi} /$ $\mathrm{ml}$; Amersham), $400 \mu \mathrm{M}$ ATP, $400 \mu \mathrm{M}$ GTP, 10 mM dithiothreitol (DTT), $20 \cup$ RNase inhibitor, and $6 U$ appropriate RNA polymerase. To generate a nonradioactive labeled probe, digoxigenin-UTP (Dig-UTP; Boehringer Mannheim, Indianapolis, IN) was used. Linearized plasmid (1 $\mu \mathrm{g}$ ) was incubated at $37^{\circ} \mathrm{C}$ for 2 hours in $1 \times$ transcription buffer, $400 \mu \mathrm{M}$ ATP, $400 \mu \mathrm{M}$ CTP, $400 \mu \mathrm{M}$ GTP, 80-260 $\mu \mathrm{M}$ UTP, 140-320 $\mu \mathrm{M}$ Dig-UTP (total UTP + Dig-UTP $=400$ $\mu \mathrm{M}), 10 \mathrm{mM}$ DTT, $20 \mathrm{U}$ RNase inhibitor, and $6 \mathrm{U}$ appropriate RNA polymerase. The resulting probes were separated from free nucleotides on a Sephadex G50-50 column. The fractions containing Dig-UTP-labeled probe were determined by performing a small-scale color reaction (see below) on $1 \mu$ l each fraction blotted onto Nytran membrane.

Before hybridization, brain sections were placed in $4 \%$ phosphate-buffered paraformal dehyde and fixed for 1 hour at room temperature. Sections were rinsed three times in $2 \times$ standard saline citrate (SSC; $1 \times$ SSC $=150 \mathrm{mM}$ sodium chloride and $15 \mathrm{mM}$ sodium citrate). Slides were then placed in a solution of $0.1 \mathrm{M}$ triethanolamine with $0.25 \%$ acetic acid for 10 minutes. The tissue was rinsed in water and dehydrated through a series of alcohols.

Dig-UTP- and [35S]-labeled probes were diluted together in hybridization buffer (50\% formamide; $10 \%$ dextran sulfate; $3 \times$ SSC; 50 mM sodium phosphate buffer, $\mathrm{pH} 7.4$; $1 \times$ Denhardt's solution; $0.1 \mathrm{mg} / \mathrm{ml}$ yeast tRNA; and 10 mM DTT) to yield an approximate concentration of 2-2.5 $\times$ $10^{6}$ c.p.m./65 $\mu$ l. Appropriate dilutions for nonradioactive probes were estimated from pilot experiments. The following probe combinations were run for the BSTov and the CEAI: Dig-GAD 65/67 (used concomitantly as a marker for GABAergic neurons) with [35S]-ENK, [35S]-NT, or [35S]$\mathrm{CRH}$ in naïve animals; Dig-ENK, Dig-NT, or Dig-CRH with [35S]-GAD 65/67 in naive animals; Dig-ENK with [35S]-NT or [ $\left.{ }^{35} \mathrm{~S}\right]-\mathrm{CRH}$ in naive animals; Dig-c-fos with [35S]-GAD 65/67, [35S]-ENK, [35S]-NT, or [ ${ }^{35 S}$ ]-CRH in animals treated with I L-1 $\beta, 5 \mu \mathrm{g} / \mathrm{kg}$ i.p. Diluted probe (65 $\mu$ ) was placed on each slide, and the sections coverslipped. Slides were placed in plastic trays lined with filter paper dampened with $50 \%$ formamide $/ 50 \%$ water. Trays were sealed and incubated at $55^{\circ} \mathrm{C}$ for 16 hours. Coverslips were floated off in $2 \times$ SSC, and slides were rinsed an additional three times in $2 \times$ SSC. Sections were incubated in RN ase $\mathrm{A}(200 \mu \mathrm{g} / \mathrm{ml})$ at $37^{\circ} \mathrm{C}$ for 60 minutes and rinsed in $2 \times$ SSC,
$1 \times$ SSC, $0.5 \times$ SSC, and $0.1 \times$ SSC. Tissue was washed to a final stringency of $0.1 \times \mathrm{SSC}$ at $65^{\circ} \mathrm{C}$ for 60 minutes Slides were then cooled to room temperature in $0.1 \times$ SSC.

After this posthybridization treatment, sections were processed for detection of the nonradioactive probe. Sections were rinsed in $0.1 \mathrm{M}$ phosphate buffer, $\mathrm{pH} 7.4$, and incubated for 2-4 hours at room temperature in a blocking solution $(0.25 \%$ carrageenan, $0.5 \%$ Triton-X $100,0.1 \mathrm{M}$ phosphate buffer, $\mathrm{pH}$ 7.4). Sections were then incubated at room temperature overnight with an antibody against Dig conjugated to alkaline phosphatase (sheep anti-Dig-AP, Fab fragments; Boehringer Mannheim) diluted 1:20,000 in blocking solution. Sections were then washed three times in $0.1 \mathrm{M}$ phosphate buffer, twice in Tris-buffered saline, and once in alkaline substrate buffer (ASB; $100 \mathrm{mM}$ Tris base, $50 \mathrm{mM} \mathrm{NaCl}, 50 \mathrm{mM} \mathrm{MgCl}_{2}, \mathrm{pH}$ 9.5). The color reaction was carried out in the dark at room temperature in ASB containing 5\% polyvinyl al cohol (Sigma, St. Louis, MO), 0.025\% levamisole (Sigma), 0.45\% 4-nitro blue tetrazolium chloride (NBT; Boehringer Mannheim) and $0.35 \%$ 5-bromo-4-chloro-3-indoyl-phosphate, 4-toluidine salt (BCIP; Boehringer Mannheim). The color reaction took 6-24 hours, depending on the probe, and sections were examined under a microscopeto determine reaction completion. Slides were then washed extensively in water. Sections were incubated in $0.1 \mathrm{M}$ glycine and $0.5 \%$ Triton-X $100, \mathrm{pH} 2.2$, for 10 minutes at room temperature to remove the antibody (Hauptmann and Gerster, 1994) and then washed in water. Finally, sections were fixed in $2.5 \%$ glutaraldehyde for 1 hour, washed in water, and air dried. The glycine and glutaraldehyde steps were found to help prevent the increase in color background observed after the development of emulsion dipped slides (see below). Sections initially were exposed to x-ray film (Biomax-MR; Eastman-K odak, Rochester, NY) for 1-3 days, then dipped in emulsion (Ilford KD-5; Polysciences, Warrington, PA), and stored in light-tight boxes at $4^{\circ} \mathrm{C}$ for 2-14 days. After devel opment (Kodak D-19) of dipped slides, sections were either coverslipped with an aqueous mounting medium (Polysciences), which enabled the visualization of white matter tracts that were used as anatomical landmarks, or dehydrated in alcohols and then mounted in a xylenebased mounting medium (Permount) for photomicrographs.

\section{Data analysis}

The cellular distribution of different mRNA combinations from dual I SH experiments was determined by using a Leica microscope (Leitz DMR; Wetzlar, Germany). Nonradi oactive riboprobes were visualized under brightfield as a blue-purple precipitate, whereas radioactive probes were visualized under darkfield by using silver grain distribution. Sections at $60-160 \mu \mathrm{m}$ intervals from three to six animals per group were analyzed throughout the rostralcaudal extent of the BSTov and the CEAI. Cell profile counts were determined at $\times 40$ magnification with the aid of an eye-piece grid ( $500 \mu \mathrm{m} \times 500 \mu \mathrm{m}$ divided into 100 squares). No attempt was made to establish absolute numbers of cells within these structures. Rather, the numbers of cell profiles counted for each animal were used to cal culate the relative percent col ocalization of mRNA for that animal. The mean \pm S.E.M. percent colocalization for each probe combination with respect to the nonradioactive probe (see Technical considerations, below) is reported in 
TABLE 1. Coexpression of Enkephalin, Neurotensin, Corticotropin-Releasing Hormone, and Glutamic Acid Decarboxylase 65/67 mRNAs in the Oval Nucleus of the Bed Nucleus of the Stria Terminalis and the Lateral Division of the Central Nucleus of the Amygdala ${ }^{1}$

\begin{tabular}{|c|c|c|c|c|c|c|c|}
\hline Dig-marker & {$\left[{ }^{35} \mathrm{~S}\right] \mathrm{marker}$} & $\begin{array}{l}\text { Dig only } \\
\text { (no. cells) }\end{array}$ & $\begin{array}{l}{[35 \text { S] only }} \\
\text { (no. cells) }\end{array}$ & $\begin{array}{l}\text { Doubles } \\
\text { (no. cells) }\end{array}$ & $\begin{array}{c}\text { Double } \\
\text { w.r.t. Dig (\%) }\end{array}$ & S.E.M. & No. \\
\hline \multicolumn{8}{|l|}{ BSTOV } \\
\hline \multicolumn{8}{|c|}{ Expression of GAD65/67 mRNA in cells containing ENK, NT, or CRH mRNA } \\
\hline ENK & GADs & 0 & nc & 781 & 100 & 0 & 3 \\
\hline NT & GADs & 0 & nc & 151 & 100 & 0 & 3 \\
\hline $\mathrm{CRH}$ & GADs & 0 & nc & 427 & 100 & 0 & 4 \\
\hline \multicolumn{8}{|c|}{ Expression of ENK, NT, or CRH mRNA in cells expressing GAD65/67 mRNA } \\
\hline GADs & ENK & 632 & nc & 432 & 41 & 3.1 & 3 \\
\hline GADs & NT & 505 & 98 & 360 & 43 & 4.1 & 3 \\
\hline GADs & $\mathrm{CRH}$ & 1,913 & 142 & 587 & 24 & 3.2 & 3 \\
\hline \multicolumn{8}{|c|}{ Expression of NT or CRH mRNA in cells expressing ENK mRNA2 } \\
\hline ENK & NT & 900 & 321 & 103 & 10 & 0.9 & 3 \\
\hline ENK & $\mathrm{CRH}$ & 947 & 382 & 10 & 1 & 0.4 & 3 \\
\hline \multicolumn{8}{|l|}{$\mathrm{CEAI}^{3}$} \\
\hline \multicolumn{8}{|c|}{ Expression of GAD65/67 mRNA in cells containing ENK, NT, or CRH mRNA } \\
\hline ENK & GADs & 0 & 2,045 & 4,507 & 100 & 0 & 4 \\
\hline NT & GADs & 0 & nc & 309 & 100 & 0 & 4 \\
\hline $\mathrm{CRH}$ & GADs & 0 & $\mathrm{nc}$ & 464 & 100 & 0 & 4 \\
\hline \multicolumn{8}{|c|}{ Expression of ENK, NT, or CRH mRNA in cells expressing GAD65/67 mRNA } \\
\hline GADs & ENK & 1,639 & nc & 5,328 & 77 & 4.1 & 4 \\
\hline GADs & NT & 2,450 & 215 & 1,116 & 32 & 0.9 & 3 \\
\hline GADs & $\mathrm{CRH}$ & 2,241 & 161 & 698 & 24 & 1.5 & 3 \\
\hline \multicolumn{8}{|c|}{ Expression of NT or CRH mRNA in cells expressing ENK mRNA 2} \\
\hline ENK & NT & 6,777 & 1,425 & 629 & 9 & 1.0 & 5 \\
\hline ENK & $\mathrm{CRH}$ & 2,581 & 729 & 13 & 0.5 & 0.1 & 4 \\
\hline
\end{tabular}

${ }^{1}$ Total cell counts for double in situ hybridization experiments in the oval nucleus of the bed nucleus of the stria terminalis (BSTov) and the lateral division of the central nucleus of the amygdala (CEAI) for the expression of mRNA encoding glutamic acid decarboxylase isoforms 65 and 67 (GADs) in cells expressing enkephalin (ENK), neurotensin (NT), or corticotropin-releasing hormone (CRH) mRNA; and the expression of mRNAs encoding the peptides ENK, NT, or CRH in cells expressing GAD65/67 mRNA. Note that "no. cells" represents the total number of cells counted for all animals. The percent of colocalization was calculated relative to the digoxigenin (Dig) probe for each animal separately, according to the following formula: no. doubles $\div$ (no. doubles + no. Dig-only) $\times 100$. The mean percentage colocalization relative to the Dig-labeled probe was calculated from these values. w.r.t., with respect to; S.E.M., standard error of the mean; nc, not counted.

2The expression of mRNAs encoding the peptides NT or CRH in ENK mRNA-containing neurons.

${ }^{3} \mathrm{~N}$ ote that cell counts were taken within the area of peak expression for each peptide mRNA, but there was significant variation in the percentage of colocalization across the region due to the differential mRNA distribution.

TABLE 2. Coexpression of c-fos mRNA With Enkephalin, Neurotensin, Corticotropin-Releasing Hormone, or Glutamic Acid Decarboxylase 65/67 mRNAs in the Oval Nucleus of the Bed Nucleus of the Stria Terminalis and Lateral Division of the Central Nucleus of the Amygdala

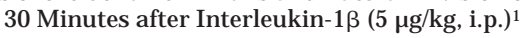

\begin{tabular}{|c|c|c|c|c|c|c|c|}
\hline Dig-marker & [35S]marker & $\begin{array}{l}\text { Dig only } \\
\text { (no. cells) }\end{array}$ & $\begin{array}{l}\text { [35S] only } \\
\text { (no. cells) }\end{array}$ & $\begin{array}{l}\text { Doubles } \\
\text { (no. cells) }\end{array}$ & $\begin{array}{c}\text { Double } \\
\text { w.r.t. Dig (\%) }\end{array}$ & S.E.M. & No. \\
\hline \multicolumn{8}{|l|}{ BSTov } \\
\hline Fos & GADs & 3 & 1,791 & 769 & 100 & 0.1 & 4 \\
\hline Fos & ENK & 110 & 1,767 & 473 & 81 & 1.4 & 4 \\
\hline Fos & NT & 401 & 1,043 & 119 & 23 & 0.5 & 4 \\
\hline Fos & $\mathrm{CRH}$ & 787 & 1,316 & 34 & 4 & 1.4 & 4 \\
\hline \multicolumn{8}{|l|}{ CEAL } \\
\hline Fos & GADs & 0 & $\mathrm{nc}$ & 4,168 & 100 & 0 & 6 \\
\hline Fos & ENK & 133 & $\mathrm{nc}$ & 2,168 & 94 & 1.3 & 4 \\
\hline Fos & NT & 1,814 & 2,012 & 468 & 22 & 1.8 & 5 \\
\hline Fos & $\mathrm{CRH}$ & 1,728 & 806 & 17 & 1 & 0.5 & 3 \\
\hline
\end{tabular}

${ }^{1}$ Total cell counts for double in situ hybridization experiments in the oval nucleus of the bed nucleus of the stria terminalis (BSTov) and the lateral division of the central nucleus of the amygdala (CEAl) for the expression of glutamic acid decarboxylase isoforms 65 and 67 (GADs), enkephalin (ENK), neurotensin (NT), or corticotropin-rel easing hormone (CRH)

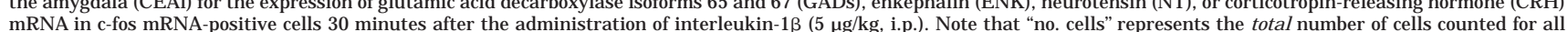
animals. The percent of colocalization was calculated relative to the digoxigenin (Dig) probe for each animal separately according to the following formula: no. doubles $\div$ (no. doubles + no. Dig-only) $\times 100$. The mean percentage col ocalization relative to the Dig-labeled probe was calculated from these values. w.r.t., with respect to; nc, not counted.

Tables 1 and 2 . The cell numbers reported in Tables 1 and 2 reflect the total numbers of cell profiles counted for all animals combined. The grid was centered over the area of peak expression of mRNA labeled with the nonradioactive probe within the boundaries of the nucleus. Neuroanatomical boundaries of the BSTov, CEAI, medial CEA (CEAm), and capsular CEA (CEAC) were determined according to the atlas of Swanson (1992) by using white matter tracts as a guide. It should be noted that the type of tissue processing involved with the dual ISH technique precluded further regional compartmentalization within the CEA. Both the left and right BSTov were included in the analysis. For the CEAI, analysis was limited to the right side. Previous quantitative results did not indicate differences in c-fos mRNA expression between the left and right sides (Day and Akil, 1996), and results from the current study did not suggest qualitative differences in the neurochemical identity of activated cells between the two sides.

\section{Photography and image processing}

With the exception of Figure 5, photomicrographs were taken by using a Zeiss Axiophot microscope (Thornwood, NY), using Kodak Tmax-100 film (for darkfield images) or Kodak Ektachrome Tungsten film (for brightfield and double-exposure dual ISH photomicrographs). Slides and negatives were converted to digital form by using a Polaroid Sprint Scanner and Adobe Photoshop software (version 4.0; Adobe Systems, Mountain View, CA) on a Macintosh computer (Apple Computers, Cupertino, CA). Images were adjusted by using one "sharpen" filter and increased brightness and contrast to allow photographicquality prints to be generated. Color images also under- 
went a color transformation (image: variations: "more blue") to provide optimal contrast between silver grains, Dig-labeled cells, and background. Each image in a composite set was processed in an identical manner. Figure 5 was generated digitally. Brightfield and darkfield images were captured separately with a Sony CCD video camera (DXC970MD; Sony Corp., Tokyo, J apan) attached to a Leica (Leitz DMR) microscope. Brightfield and darkfield images were then overlaid to produce a single image by using the MCID image-analysis system (MCID, Ontario, Canada). The composite was formed within Adobe Photoshop. Brightness and contrast were altered to the same degree for each picture within the composite to generate a photographicquality print. Schematic diagrams were adapted from the atlas of Swanson (1992) by using Adobe Illustrator (version 7.0; Adobe Systems).

\section{RE SULTS}

Initial studies indicated that the nonradioactive ISH technique was less sensitive than the radioactive ISH technique, in that the numbers of cells observed to be labeled after hybridization with a Dig-labeled probe were less than those observed with a similar [ $\left.{ }^{35} \mathrm{~S}\right]-$ label ed probe. For example, sections from the striatum of one animal were labeled concurrently with Dig-ENK and [35S]-ENK (Fig. 1A). Every cell that was positive for Dig-ENK also was positive for [ ${ }^{35}$ S]-E NK (485 cells counted). I n contrast, only $94 \%$ of cells that were positive for [ $\left.{ }^{35} \mathrm{~S}\right]-\mathrm{E}$ NK also were positive for Dig-E NK (33 cells were positive for [35S]-E NK alone). Hence, the results of the current study are expressed with respect to the Dig-labeled probe (Tables 1, 2). For probe combinations in which results were required with respect to both probes, two series of sections were analyzed; for example, Dig-ENK with [35S]-GAD65/67 and Dig-GAD65/67 and [35S]-ENK.

\section{Expression of peptide mRNA in GABAergic neurons of the BST ov and CEAI}

The general patterns of expression of $\mathrm{CRH}, \mathrm{ENK}, \mathrm{NT}$, GAD65, and GAD67 mRNAs were consistent with previous reports (Harlan et al., 1987; Alexander et al., 1989; Esclapez et al., 1994; Makino et al., 1994). All of these mRNAs were expressed within the BSTov (Fig. 2) and the
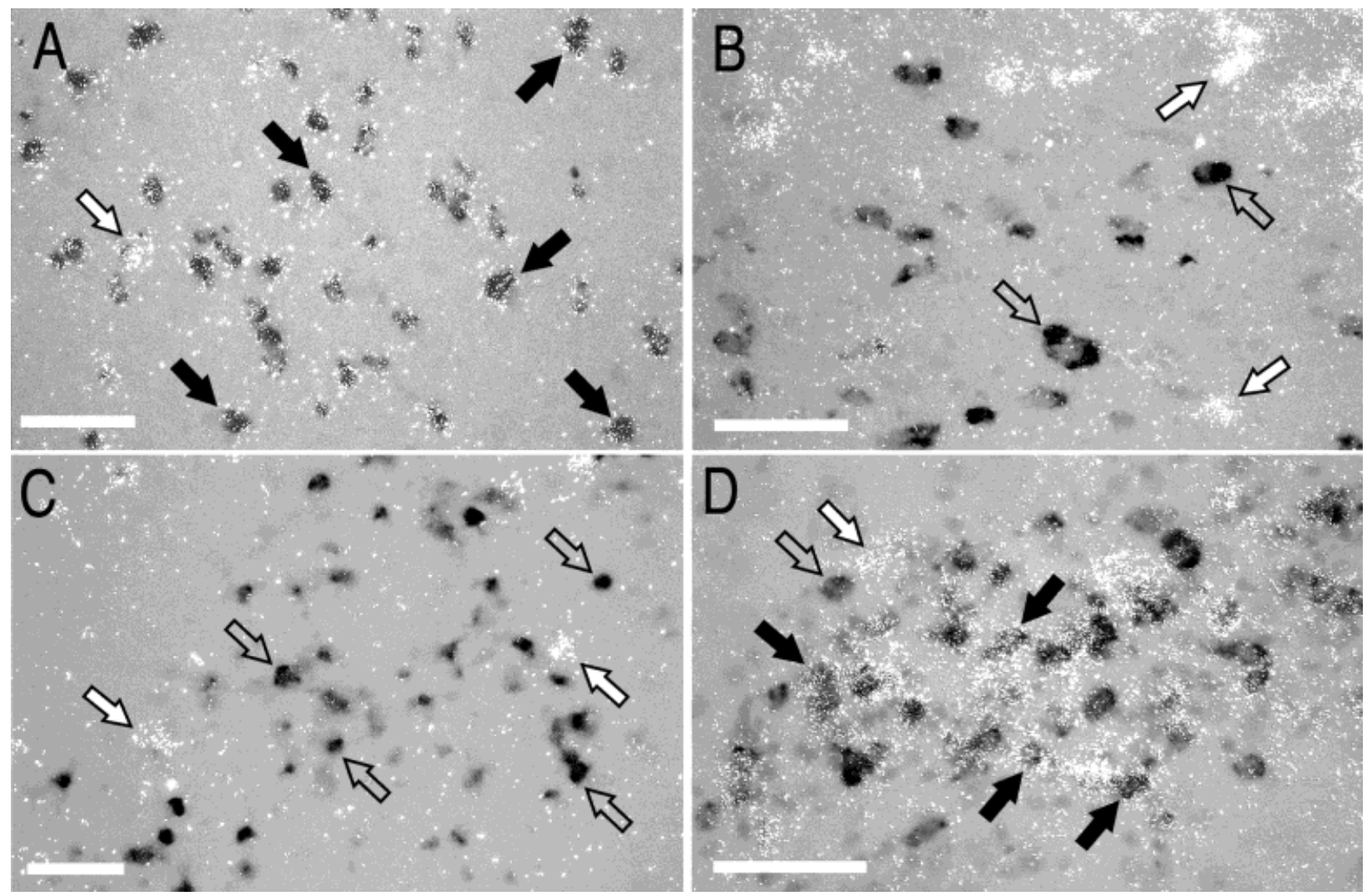

Fig. 1. Photomicrographs (double exposure) of control double in situ hybridization experiments using the following probes: A: Digoxigenin-enkephal in (Dig-ENK) $+{ }^{35}$ S] $-E N K$ in thestriatum demonstrating the extent of colocalization of the two labeled probes with one another. B: Dig-ENK + [35S]-glutamic acid decarboxylase 65/67 (GAD65/67) in the paraventricular nucleus of the hypothalamus (PVH) demonstrating thelack of colocalization of ENK and $\gamma$-aminobutyric acid (GABA) in this nucleus compared with that observed in the oval nucleus of the bed nucleus of the striatum (BSTov) and the lateral division of the central nucleus of the amygdala (CEAI). C: Dig-Fos +

[35S]-GAD65/67 in the PVH 30 minutes after interleukin-1 (IL-1 $5 \mu \mathrm{g} / \mathrm{kg}$, i.p.) demonstrating the lack of colocalization of c-fos mRNA and GABA in this nucleus compared with that observed in the BSTov and CEAI. D: Dig-F os + [35 S]-corticotropin-rel easing hormone (CRH) in the PVH 30 minutes after IL-1 $15 \mu \mathrm{g} / \mathrm{kg}$, i.p.) demonstrating the significant colocalization of c-fos and CRH MRNA in this nucleus compared with that observed in the BSTov and CEAI. Open arrows indicate cells hybridized with the Dig-labeled probe only. Solid white arrows indicate cells hybridized with the [ $\left.{ }^{35} \mathrm{~S}\right]$-labeled probe only. Sol id black arrows indicate double-labeled cells. Scale bars $=50 \mu \mathrm{m}$. 

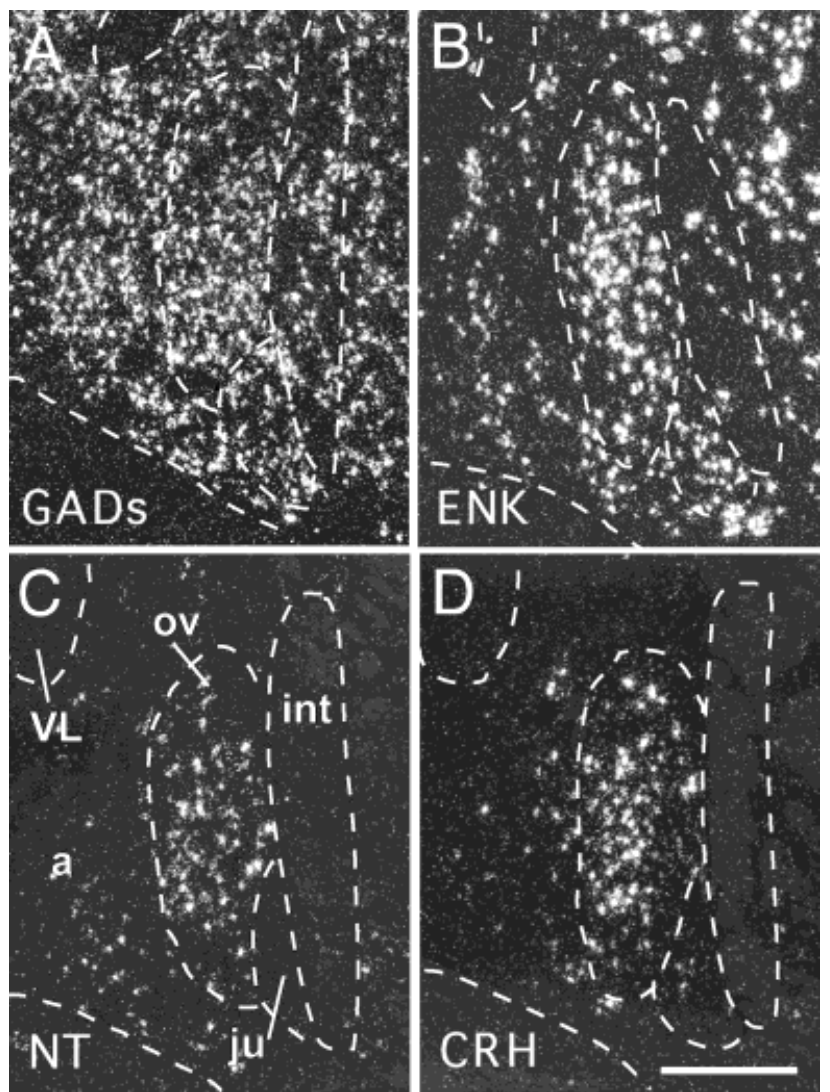

Fig. 2. Distribution of mRNA encoding GAD65/GAD67 (A), ENK (B), neurotensin (NT; C), and CRH (D) in the BSTov. Dashed lines delineate anatomical subdivisions as indicated in $\mathrm{C}$. Divisions of the bed nucleus of the stria terminalis (BST): a, anterior; ju, juxtacapsular nucleus; ov, oval nucleus; int, internal capsule; VL, lateral ventricle. Scale bar $=200 \mu \mathrm{m}$.

CEAI (Fig. 3), with GAD65/67 and ENK mRNAs more abundant than $\mathrm{CRH}$ and NT mRNAs. GABAergic and peptidergic neurons exhibited specific patterns of expression within these nuclei. GAD65 and GAD67 mRNAs were observed throughout the BST and CEA, with high levels in both the lateral and medial divisions (Figs. 2B, 3B). Expression of ENK mRNA was high throughout the BSTov (Fig. 2C) and the CEAI (Fig. 3C), but some labeled cells also were observed in the CEAm. Expression of NT mRNA was moderate in the BSTov and CEAl (Figs. 2D, 3D). Expression of NT mRNA was highest in the dorsal and medial aspects of the CEAl, with some cells also observed in the CEAm (Fig. 3D). F or CRH mRNA, expression within the BSTov was greater toward the medial extent of this nucleus (Fig. 2E). Within the CEA, CRH mRNA was localized mainly to the lateral division, with expression greatest within the central region of the CEAI (Fig. 3E). Expression of $\mathrm{CRH}$ mRNA was observed throughout the

Fig. 3. A: Schematic diagram of the CEA. B-E : Distribution in the CEA of mRNAs encoding GAD65/GAD67 (B), ENK (C), NT (D), and $\mathrm{CRH}(\mathrm{E})$. Dashed lines delineate anatomical subdivisions as indicate in A. CEAl, lateral division of the CEA; CEAm, medial division of the CEA; CEAc, capsular division of the CEA; st, stria terminalis; BLA, basolateral amygdaloid nucleus. Scale bar $=300 \mu \mathrm{m}$.
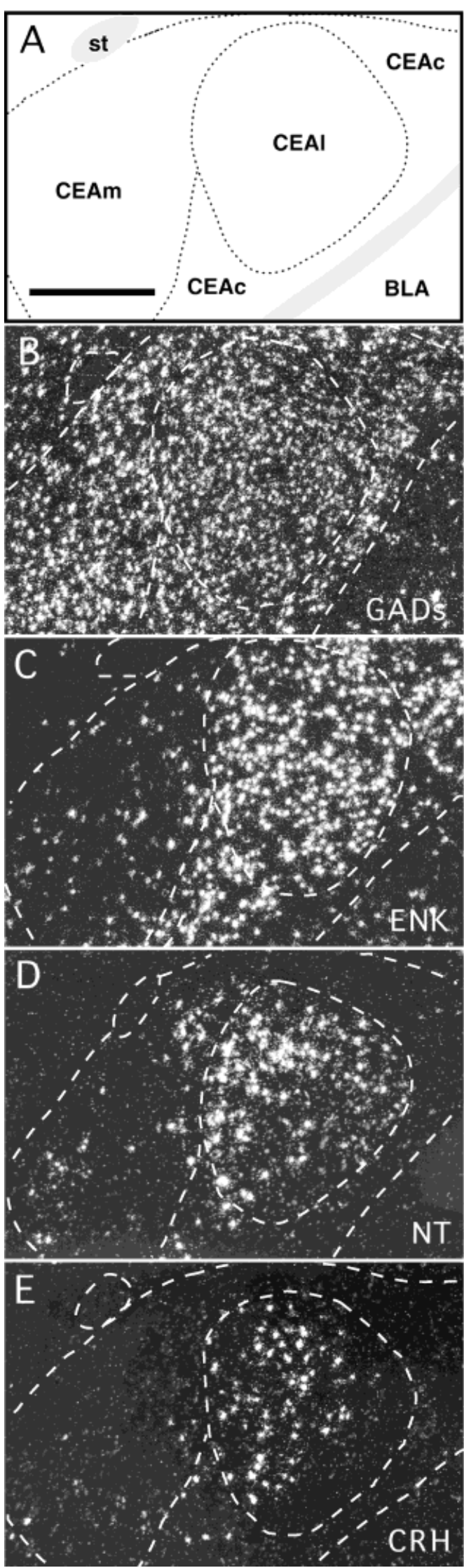
rostral-caudal extent of the CEAI but was highest at midlevels, caudal to the paraventricular nucleus of the hypothalamus (PVH).

Within the CEAI and BSTov, every cell that expressed either $\mathrm{CRH}$, ENK, or NT mRNA (Dig-labeled probe) also expressed GAD65/67 mRNA ([35S]-labeled probe; Fig. 4). The $100 \%$ colocalization of the peptide mRNAs with GAD65/67 is unlikely to be due to a nonspecific interaction of the probes. F or example, within the reticular nucleus of the thalamus, GAD65/67 mRNA did not colocalize with either CRH, ENK, or NT mRNA (data not shown). Furthermore, within the PVH, neither $\mathrm{CRH}$ nor ENK mRNA was coexpressed with GAD65/67 mRNAs (shown for DigENK with [ ${ }^{35}$ S]-GAD65/67 in Fig. 1B). However, not all GABAergic cells (Dig-labeled GAD65/67 mRNA) also contained a particular peptide mRNA ([35S]-labeled probe). The percentage of colocalization varied, particularly across the CEA, because of the differential distributions of each of the peptide mRNA species. However, the greatest colocalization for both the BSTov and the CEAI was observed for ENK, with up to $75 \%$ of GABAergic neurons containing this peptide (BSTov: $41 \% \pm 3.1 \% ; n=3$; CEAl: $77 \% \pm$ 2.1\%; $n=4)$. Fewer GABAergic cells expressed NT or $\mathrm{CRH}$. Within the area of peak expression of $\mathrm{CRH}$ in both the BSTov and the CEAl, $\approx 25 \%$ of neurons that were positive for GAD65/67 also expressed CRH mRNA (BSTov: $24 \% \pm 3.2 \% ; n=3$; CEAI: $24 \% \pm 1.5 \% ; n=3$ ). The ratio was slightly higher at the peak of NT expression (BSTov: $43 \% \pm 4.1 \% ; n=3$; CEAl: $32 \% \pm 0.9 \% ; n=3)$. The expression of NT or CRH in ENK-containing cells revealed a highly specific pattern of colocalization (Fig. 5). There was some colocalization of NT in ENK mRNA-containing cells (BSTov: $10 \% \pm 0.9 \% ; n=3$; Fig. $5 \mathrm{~A}$; CEAl: $9 \pm 1.0 \%$; $n=5$; Fig. 5B). However, extremely few ENK-positive cells
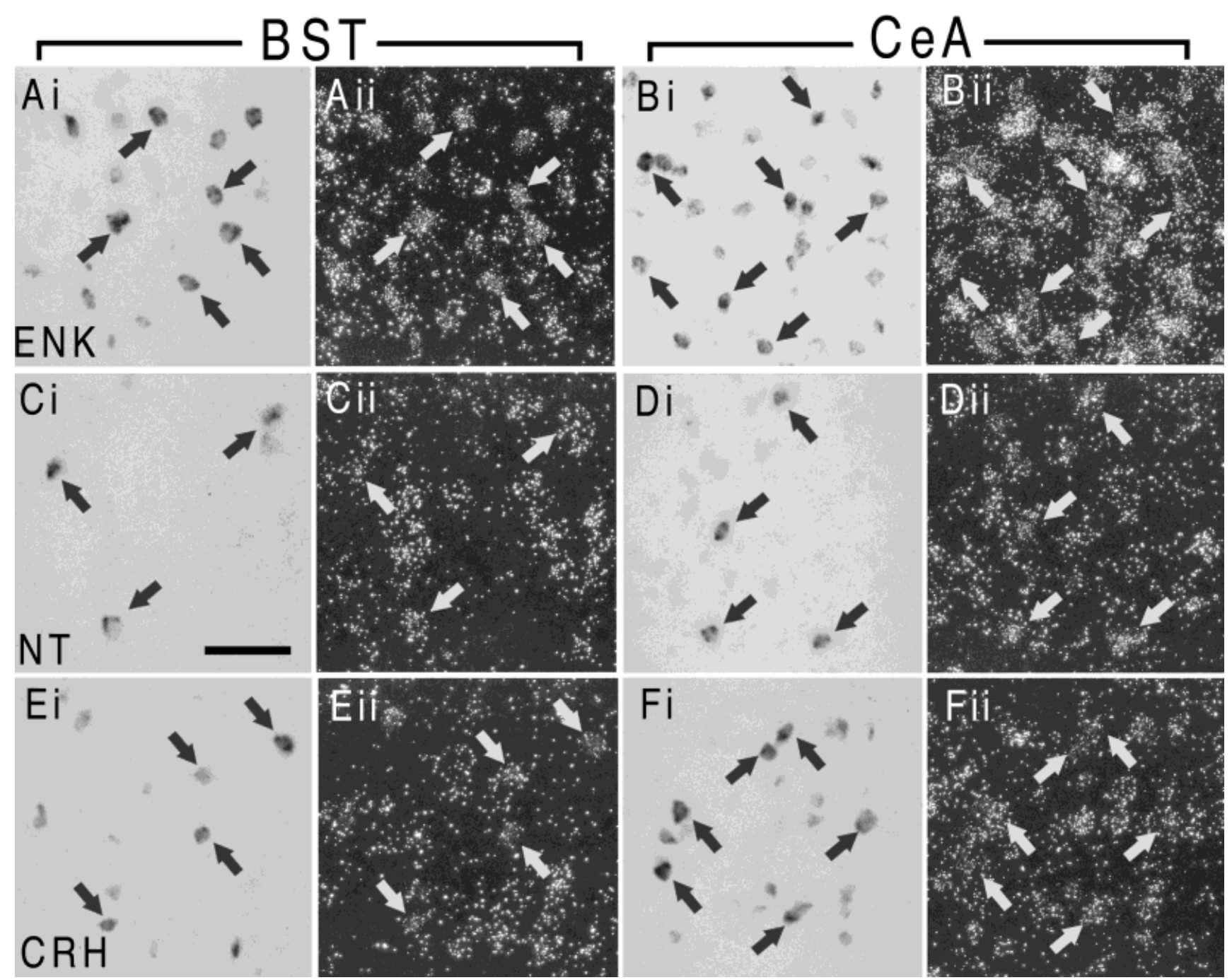

Fig. 4. A-F: Photomicrographs (single exposures) of double in situ hybridization experiments showing the colocalization of GAD65 and GAD67 mRNA ([ $\left.{ }^{35} \mathrm{~S}\right]$-labeled probe; Aii-Fii) with various peptides (Dig-labeled probe; $\mathrm{Ai}-\mathrm{Fi}$ ) in the BSTov (Ai,Aii; $\mathrm{Ci}, \mathrm{Cii} ; \mathrm{Ei}, \mathrm{Eii}$ ) and the CEAl (Bi,Bii; Di,Dii; Fi,Fii). A: Dig-ENK + [35S]-GAD65/67 in the BSTov. B: Dig-ENK + [35S]-GAD65/67 in the CEAI. C: Dig-NT + [35S]-GAD65/67 in the BSTov. D: Dig-NT + [35S]-GAD65/67 in the

CEAl. E: Dig-CRH + [35S]-GAD65/67 in the BSTov. F: Dig-CRH + [35S]-GAD65/67 in the CEAI. Dark arrows indicate cells expressing peptide mRNA (Dig-labeled probe). Light arrows indicate the same cells labeled for [35S]-GAD65/67 mRNA. Every cell that expressed either ENK, CRH, or NT al so expressed GAD65/67 mRNA. Scalebar = $50 \mu \mathrm{m}$. 

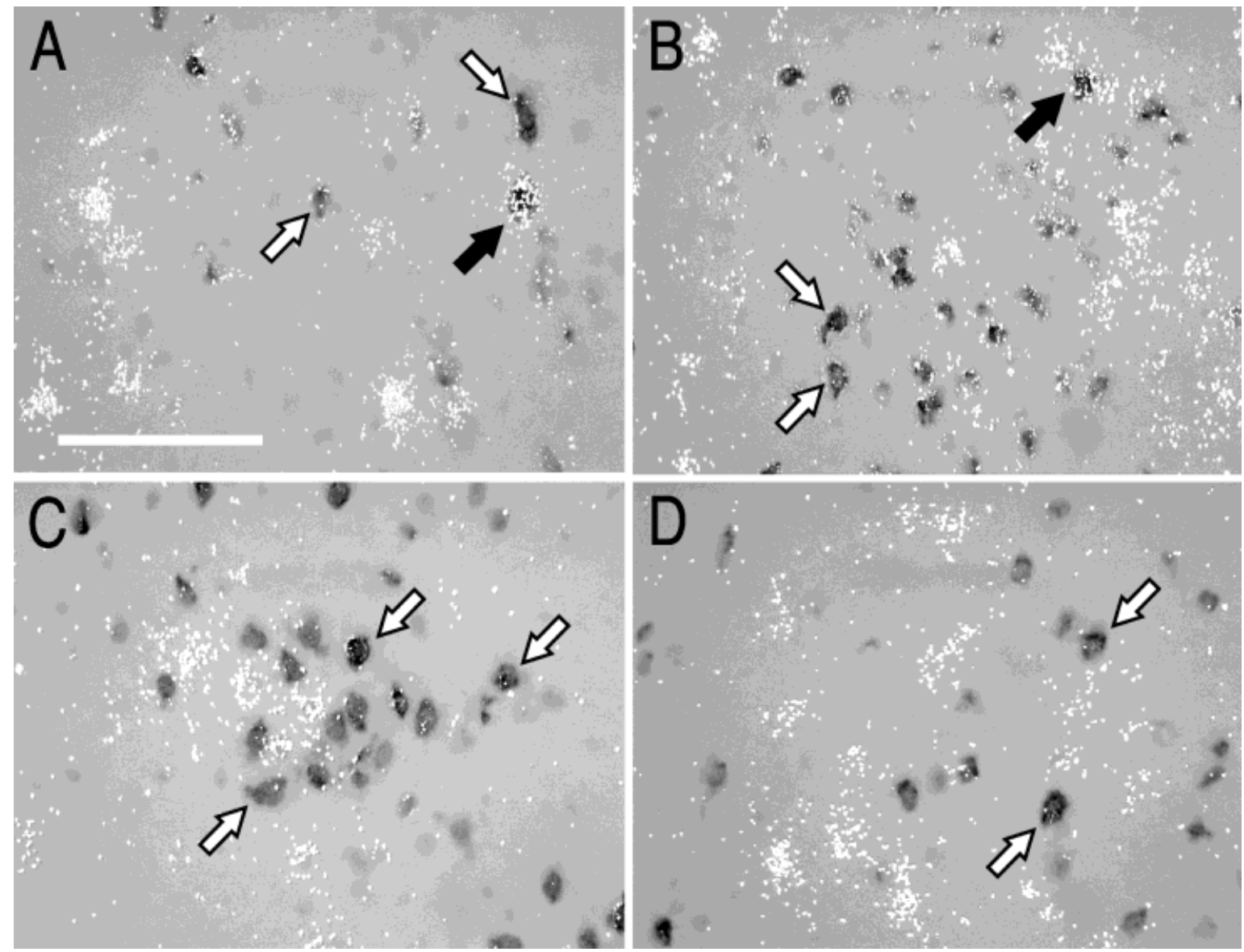

Fig. 5. Photomicrographs (double exposure) of double in situ hybridization experiments showing the extent of colocalization of ENK mRNA (Dig-labeled probe) with NT $(\mathbf{A}, \mathbf{B})$ or $\mathrm{CRH}(\mathbf{C , D})$ mRNAs

([ $\left.{ }^{35} \mathrm{~S}\right]$-labeled probes) in the BSTov $(\mathrm{A}, \mathrm{C})$ and the CEAI (B,D). White arrows indicate cells hybridized with the Dig-labeled probe only. Black arrows indicate double-labeled cells. Scale bar $=100 \mu \mathrm{m}$.

expressed CRH mRNA (BSTov: $1.2 \% \pm 0.4 \% ; n=3$; Fig. 5C; CEAl: $0.5 \% \pm 0.1 \% ; n=4$; Fig. 5D).

\section{Expression of c-fos mRNA in neurochemically defined neurons of the BST ov and CEAI}

A marked increase in c-fos mRNA expression was observed in the BST (Fig. 6) and the CEA (Fig. 7) 30 minutes after administration of IL-1 $(5 \mu \mathrm{g} / \mathrm{kg}$, i.p. $)$ compared with sal ine-injected controls, consistent with results from previous studies (Brady et al., 1994; Day and Akil, 1996). Within the BST, expression was highly discrete, with the majority of labeled cells observed within the BSTov. Furthermore, expression of c-fos mRNA within the BSTov was most abundant toward the lateral extent of this nucleus. Expression of c-fos mRNA within the CEA was localized essentially to the CEAl, with very few labeled cells observed in the CEAm or CEAc. Expression of c-fos mRNA was observed throughout the CEAl but was strongest in the ventrolateral region, caudal to the $\mathrm{PVH}$.

The IL-1 $\beta$-induced expression of $\mathrm{c}$-fos mRNA in cells of the BSTov and CEAI was determined with respect to colocalization in GABAergic (as defined by the expression of GAD65 and/or GAD67 mRNA) or peptidergic (CRH, ENK, or NT mRNA-containing) cells. A striking parallel was noted between the neurochemical identity of Fos-

positive cells in the BSTov and CEAI, as shown in Figures 8 and 9. Cells that expressed c-fos mRNA in either the BSTov (Figs. 8A, 9) or the CEAI (Figs. 8B, 9) invariably expressed GAD65/67 mRNA (BSTov, $\mathrm{n}=4$; CEAI, $\mathrm{n}=6$ ). The $100 \%$ col ocalization of c-fos mRNA in GABAergic cells was specific for these nuclei. Other areas that expressed GAD65/67 mRNA, for example, the reticular thalamic nudeus, did not express c-fos mRNA (data not shown), and c-fos mRNA-containing cells of the PVH did not express GAD65/67 mRNA (Fig. 1C). I n addition, in both the BSTov (Figs. 8C, 9) and the CEAl (Figs. 8D, 9), the majority of cells expressing c-fos mRNA in the BSTov $(81 \% \pm 1.4 \%$; $n=4)$ and CEAI $(94 \% \pm 1.3 \% ; n=4)$ al so expressed ENK mRNA. A smaller population of cells positive for c-fos mRNA in the BSTov (Figs. 8E, 9) and CEAI (Figs. 8F, 9) expressed NT mRNA (BSTov: $23 \% \pm 0.5 \% ; n=4$; CEA: $22 \% \pm 1.8 \% ; n=5)$. Very few cells that expressed c-fos mRNA in the BSTov (Figs. 8G, 9) and CEAl (Figs. 8H, 9) also expressed $\mathrm{CRH}$ mRNA (BSTov: $4 \% \pm 1.4 \% ; n=4$; CEA: $1 \% \pm 0.5 \% ; n=3$ ). This result is in contrast to that observed for $\mathrm{CRH}$ and $\mathrm{c}$-fos mRNAs in the $\mathrm{PVH}$, where there is substantial overlap of expression (Fig. 1D), in agreement with previous observations after intravenous infusion of IL-1 $\beta$ (Veening et al., 1993; Ericsson et al., 1994). 

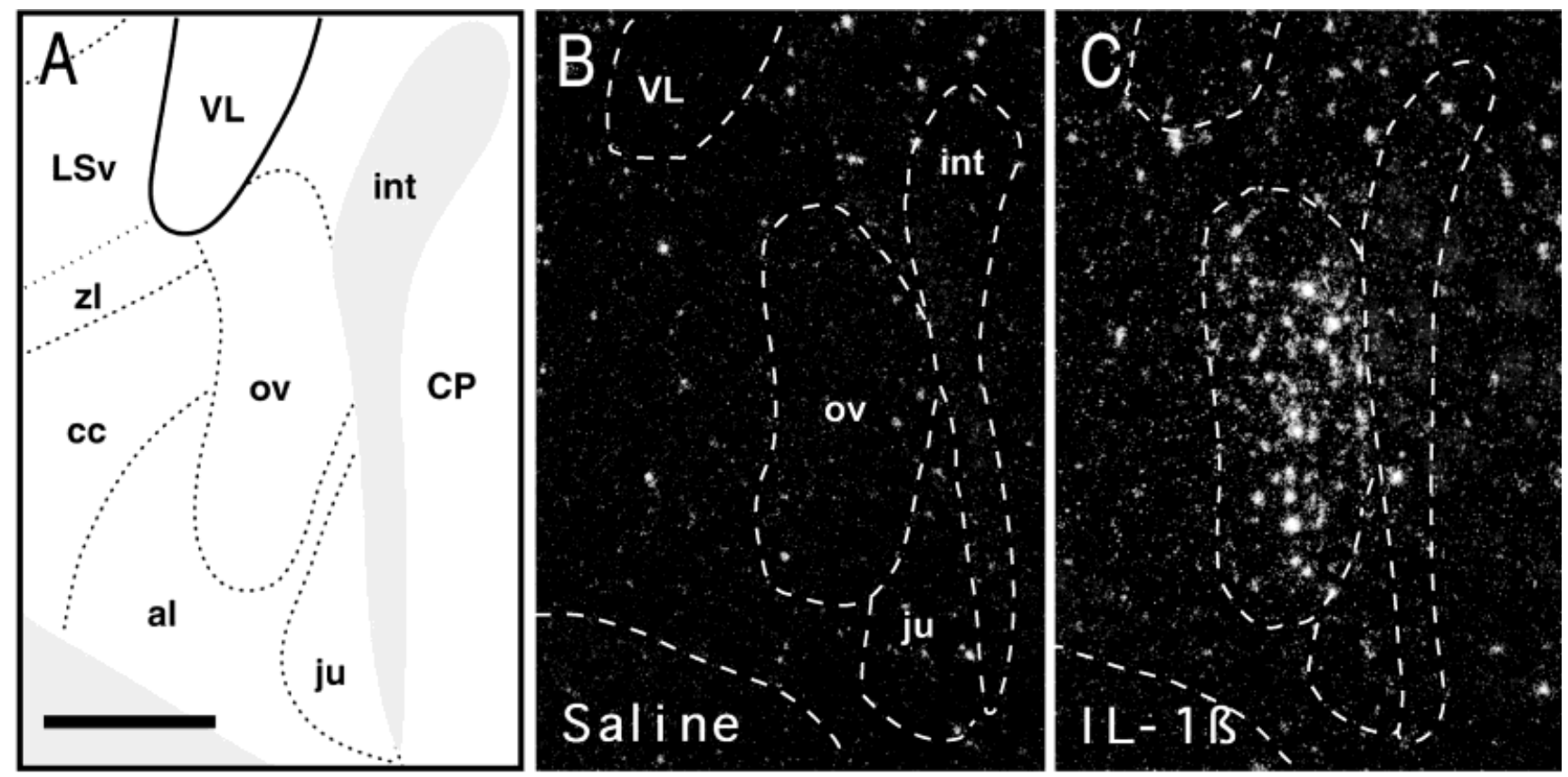

Fig. 6. A: Schematic diagram of the BSTov. B,C: Distribution of c-fos mRNA in the BSTov 30 minutes after administration of $0.9 \%$

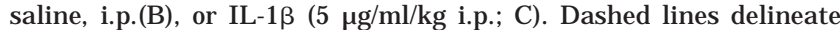
anatomical subdivisions as indicated in $\mathrm{B}$. Divisions of the anterior

\section{DISCUSSION}

The data presented in the current study provide evidence for neurochemically distinct subsets of cells in the BSTov and CEAI and suggest that these subpopulations may be activated differentially by systemic IL-1 $\beta$. The mRNA encoding for the peptides ENK, NT, and CRH invariably is expressed in GABAergic cells in these regions. Although there is some colocalization of ENK and NT mRNAs, enkephalinergic cells rarely express CRH mRNA in either the BSTov or the CEAI. The demonstration that systemic administration of $I L-1 \beta$ causes the robust activation of enkephalinergic cells but extremely sparse activation of $\mathrm{CRH}$-containing cells (as determined by c-fos mRNA expression) suggests that these neurochemically defined neuronal subsets of the BSTov and CE Al may have differential functions. F urthermore, the proportion of neurochemically similar and functionally activated cells showed remarkable similarities between the BSTov and the CEAl, consistent with the concept of an extended amygdala.

\section{Technical considerations}

In general, the dual-ISH method is a powerful tool for studying the colocalization of two molecules in a single neuron. This technique has the advantage over some dual-immunocytochemistry methods, because it can be used in animals without the severe stress of colchicine pretreatment. However, for each combination of probes, a number of considerations must be taken into account before results can be validated. F or example, tissue with different levels of expression should be used to control for nonspecific probe interactions in cases in which a high degree of colocalization is observed and to control for quenching when a low degree of colocalization is observed.
BST: al, anterolateral area; $c$, central core, anterodorsal area; ju, juxtacapsular nucleus; ov, oval nucleus; CP, caudate putamen; int, internal capsule; LSv, lateral septal nucleus, ventral part; VL, lateral ventricle; zl, zona limitans. Scale bar $=200 \mu \mathrm{m}$.

Specific examples are described in the Results (above) and are illustrated in Figure 1. Furthermore, a particular consideration lies in the fact that the nonradioactive ISH technique is less sensitive than the radioactive ISH technique, so that the numbers of cells observed to be labeled after hybridization with a Dig-labeled probe are less than those observed with a similar [35S]-labeled probe. Because of this technical limitation, the results expressed relative to the [ $\left.{ }^{35} \mathrm{~S}\right]-$-labeled probe are misleading, because they underestimate the proportion of double-labeled cells. Hence, data from the current study were expressed with respect to the Dig-labeled probe. It also should be noted that a cell profile count methodology was used to generate these data, which inherently leads to a biased count of absolute cell numbers (Coggeshall and Lekan, 1996). However, we did not attempt to determine the absolute numbers of cells, and this counting method is suitable to estimate the approximate proportion of cells expressing a particular mRNA (Saper, 1996). Caution also must be exercised when interpreting c-fos mRNA expression and, more specifically, the lack of expression of this gene in different cell populations. In particular, the lack of expression in CRH mRNA-containing cells is discussed in detail below. Finally, it should be kept in mind that a single dose of IL-1 $\beta$, and a single time point was used in the present study. The experimental conditions, as discussed in more detail below, were chosen to elicit a robust increase in c-fos mRNA expression at the time of peak expression. Although a dose-response curve was not run in the present experiment, the dose used was comparable to that used in several other studies. F or example, studies to establish the role of vagal afferents after intraperitoneal administration

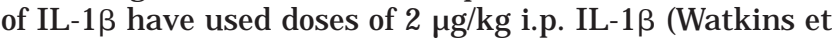



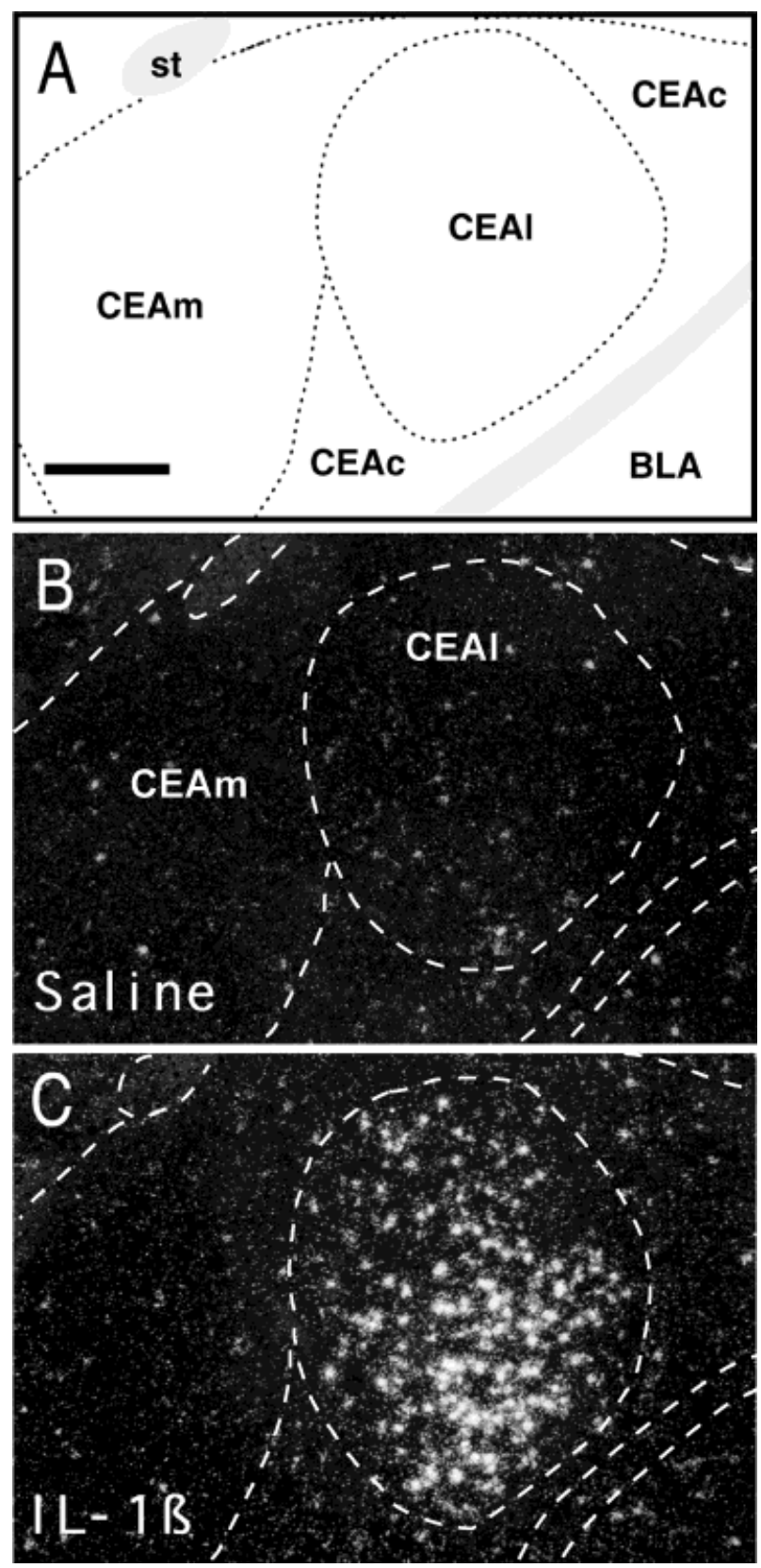

Fig. 7. A: Schematic diagram of the central nucleus of the amygdala (CEA). B,C: The distribution of c-fos mRNA 30 minutes after administration of $0.9 \%$ saline, i.p. (B) or IL-1 $(5 \mu \mathrm{g} / \mathrm{ml} / \mathrm{kg}$, i.p.; C). Dashed lines delineate anatomical subdivisions as indicated in A. For abbreviations, see Figure 3 . Scale bar $=200 \mu \mathrm{m}$.

al., 1995), $10 \mu \mathrm{g} / \mathrm{kg}$ i.p. I L-1ß (Fleshner et al., 1995), and 4 $\mu \mathrm{g} / \mathrm{kg}$ or $20 \mu \mathrm{g} / \mathrm{kg}$ i.p. I L-1 $\beta$ (Kapcala et al., 1996).

\section{Neurochemical determination of subpopulations of neurons of the BST ov and CEAI}

It has long been known that the BSTov and CEAl are highly GABAergic (Sun and Cassell, 1993) and that opioid peptide-like immunoreactivity is localized in GABAergic neurons of the rat CEA (Oertel et al., 1983). More recently, a study using immunocytochemistry on adjacent sections suggested that GABAergic neurons of the central extended amygdala synthesize either CRH or ENK (Veinante et al., 1997). However, the extent of colocalization of different peptides in GABAergic cells has not been demonstrated previously. Data presented in this paper suggest that every cell that expresses ENK, NT, or CRH mRNA in the BSTov and CEAl is GABAergic. However, as expected, not all GABAergic cells in these regions express the mRNA encoding these peptides. In addition, it is important to note the widespread expression of GAD65/67 mRNA observed in the medial division of the CEA, the major source of CEA efferent projections. In keeping with this, it has been demonstrated recently that efferents from the CEA form inhibitory type synapses with neurons in the rat NTS (Pickel et al., 1995) and that the CEA projection to the medulla is mostly GABAergic (J ia et al., 1997). Together, these data suggest that the major output of the CEA may be inhibitory rather than excitatory. Within the BSTov and $\mathrm{CEAI}, \approx 10 \%$ enkephalinergic neurons were found to coexpress NT mRNA, whereas enkephalinergic neurons rarely expressed CRH mRNA. Although we did not investigate the overlap between NT and $\mathrm{CRH}$ mRNAs in the present study, a previous study has shown that $80 \%$ of NT cells in theBSTov and $80-90 \%$ of NT cells in the CEAI were immunoreactive for CRH (Shimada et al., 1989). Hence, there appear to be two major subpopulations of GABAergic neurons: one containing $\mathrm{CRH}$ and one containing ENK, with NT expressed to differing extents within these neurons.

The potential activation of these distinctive neuronal subpopulations was investigated after i.p. administration of I L-1 $\beta$, because our group and others have demonstrated that this stimulus results in activation of both the BSTov and the CEAI, as determined by the expression of c-fos mRNA. Although it was not demonstrated directly, the data presented in the current study suggest that the majority of the I L-1 $\beta$-responsive neurons of the BSTov and CEAI contain both GAD65/67 and ENK mRNAs. Smaller proportions of activated neurons appear to contain both GAD65/67 and NT mRNAs. It is not clear whether these represent distinct populations or whether some of the activated GABAergic neurons express both NT and ENK. However, despite the generally high degree of colocalization between CRH and NT (Shimada et al., 1989), it seems likely that, given the lack of colocalization of $\mathrm{CRH}$ and c-fos mRNAs, the NT mRNA-containing cells that were activated by IL-1 $\beta$ represent a specific subpopulation of NT cells that do not contain $\mathrm{CRH}$.

The lack of c-fos mRNA in $\mathrm{CRH}$ cells is difficult to interpret definitively. It is unlikely that $\mathrm{CRH}$-containing cells are unable to express c-fos mRNA, because they have been shown to express F os protein after nicotine administration (Matta et al., 1997). It also is possible that a different dose of IL-1 $\beta$ or a different time after injection would elicit c-fos mRNA expression in CRH cells. However, we believe that this is unlikely, because the dose employed in this study was relatively high, and c-fos mRNA peaks early in these areas after i.p. injection and returns to basal levels after 3 hours (Brady et al., 1994). It is not clear from the present data whether or not i.p. IL-1 $\beta$ increases expression of other transcription factors in CRH mRNAcontaining cells, and the lack of expression of c-fos mRNA certainly does not predude these cells from being involved in the coordinated response of the animal to this stimulus. 

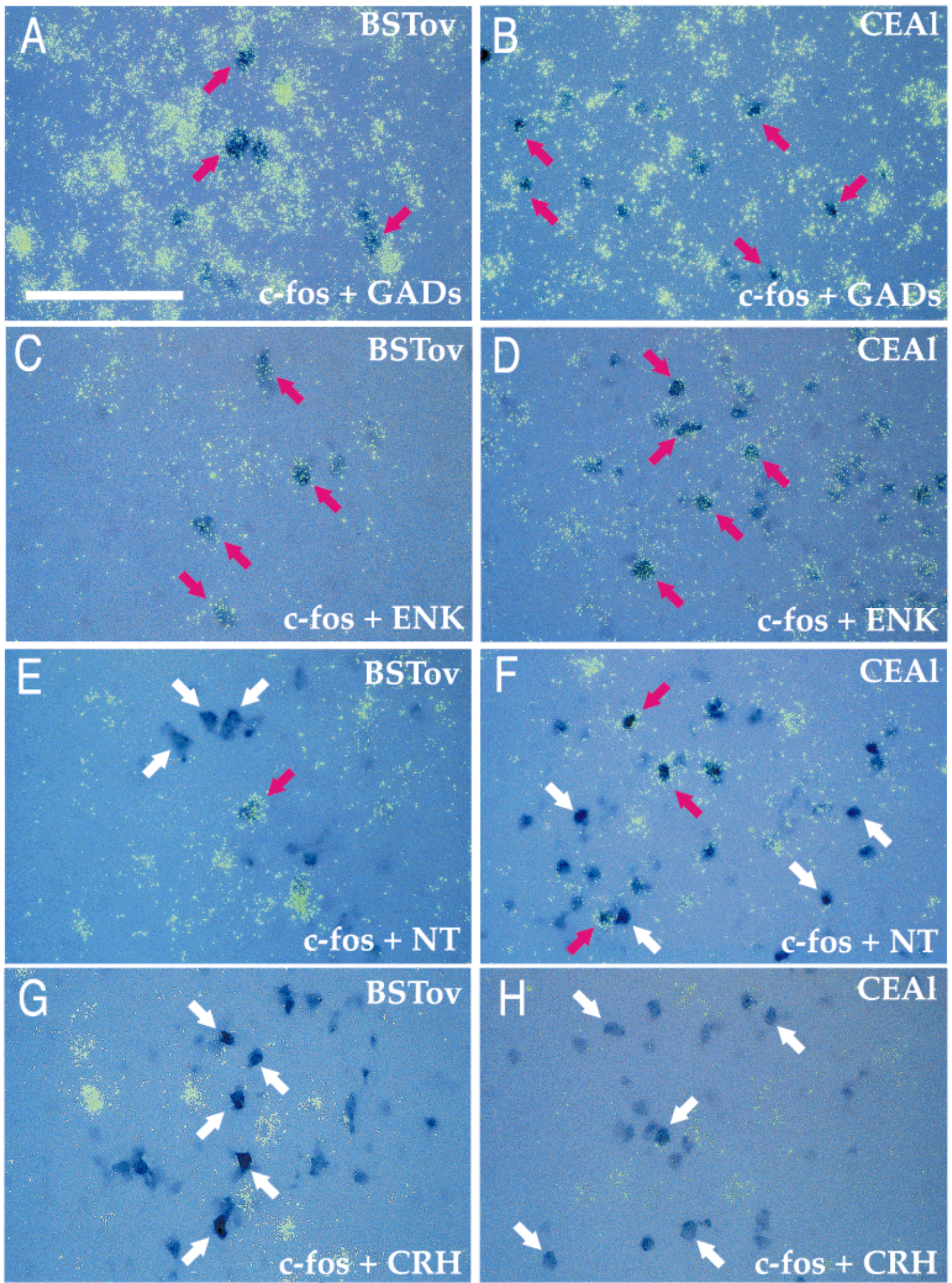

Fig. 8. Photomicrographs (double exposure) of double in situ hybridization experiments showing the extent of col ocalization of c-fos mRNA (Dig-labeled probe) 30 minutes after IL-1 $\beta$ administration $(5 \mu \mathrm{g} / \mathrm{ml} / \mathrm{kg}$, i.p.) with GAD65 and GAD67 (A,B), ENK (C,D), NT (E, F), and CRH $(\mathbf{G}, \mathbf{H})$ mRNAs $\left(\left[{ }^{35} \mathrm{~S}\right]\right.$-labeled probes) in the BSTov $(A, C, E, G)$

and the CEAI (B,D,F,H). White arrows indicate cells that contain c-fos mRNA alone. Magenta arrows indicate double-labeled cells that contain c-fos mRNA with the appropriate radioactive-labeled marker. Scale bar $=100 \mu \mathrm{m}$ 


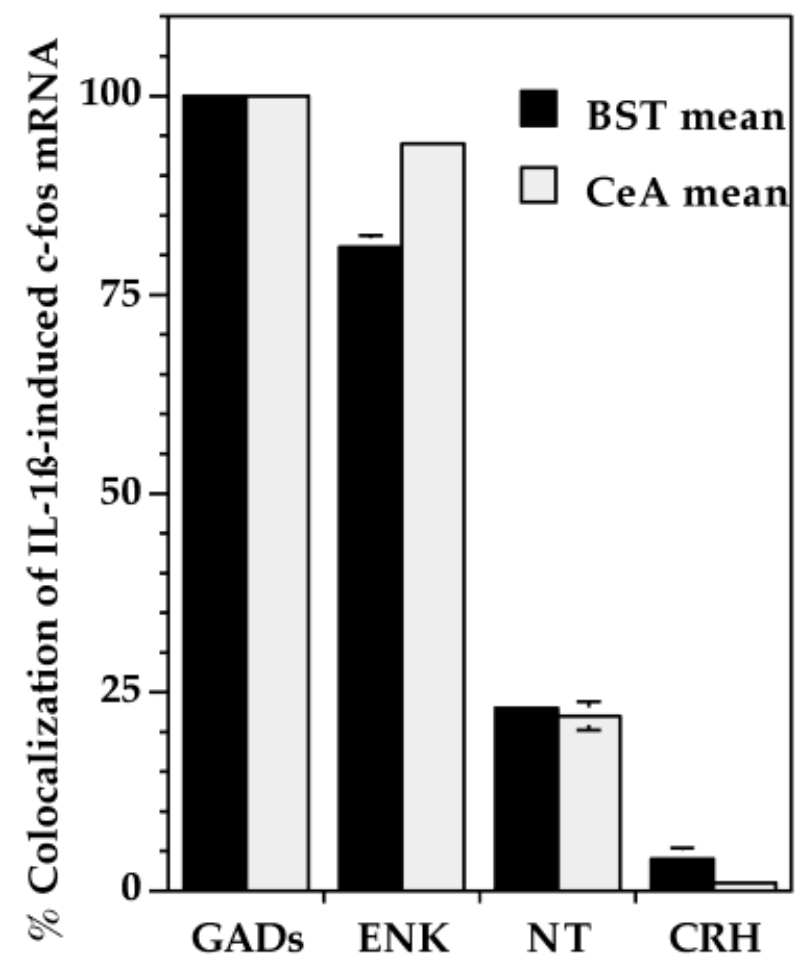

Fig. 9. Graph illustrating the relative proportions of c-fos mRNA expressing cells in the BSTov and the CEAl that expressed either GAD65/67, ENK, NT or CRH mRNA, 30 minutes after administration of IL-1 $\beta(5 \mu \mathrm{g} / \mathrm{kg}$, i.p.).

However, we believe it is most likely that these cells are under active inhibition, as is discussed below. Nevertheless, the present data indicatethe existence of neurochemically distinctive subpopulations within the BSTov and CEAl and suggest that they may represent functionally discrete neural circuits that may be activated differentially by a specific stimulus.

\section{Potential functional implications} of activation of the BST ov and CE AI by IL-1及

Although, currently, there are no data regarding specific functional roles for $\mathrm{CRH}$ - versus ENK-containing cells of the BSTov and CEAl, we hypothesize that differential activation of these neurochemically distinct neuronal populations allows the BSTov and CEAI to subserve different functional roles. The similarities in c-fos $\mathrm{mRNA}$ expression between the two nuclei are consistent with the anatomical concept of an extended amygdala (for review, see Alheid et al., 1995), and, broadly, these two nuclei have been linked functionally. Furthermore, it has been argued recently that the terms "amygdala"; or "amygdalar complex"; combinecell groups arbitrarily (Swanson and Petrovich, 1998); indeed, it is possible that, functionally, the CEAl would be better classified with the BSTov than within the amygdalar complex.

Of particular interest to our laboratory is the regulation of the hypothalamic-pituitary-adrenal (HPA) axis, the activation of which is a defining feature of a stress response. Several studies have indicated that both the CEA and the BST play a role in the regulation of stressinduced adrenocorticotropin hormone (ACTH) and corticosterone release, with the suggestion that this regulation is effected directly at the level of the PVH (Dunn, 1987; Gray et al., 1989, 1993). Although administration of IL-1 $\beta$ results in activation of the HPA axis (Besedovsky et al., 1986), the BSTov and CEAl express very low levels of c-fos mRNA after a variety of other stressors, induding restraint, swim stress (Cullinan et al., 1995), audiogenic stress (Campeau and Watson, 1997), and fear conditioning (Campeau et al., 1997). Hence, c-fos mRNA expression within the BSTov and CEAI is not a feature common to the central response to acute stress. Furthermore, although early anatomical evidence suggested that the CEA provides direct input to the PVH (Gray et al., 1989), more recent studies using highly discrete injections of the retrograde tracer FluoroGold into the parvocellular $(\mathrm{CRH}$ containing) regions of the $\mathrm{PVH}$ indicate that neither the BSTov nor the CEA provide direct input to the parvocellular PVH (Cullinan et al., 1996; Prewitt and Herman, 1998). Of particular relevance is the recent study of Lee et al. (1998), who described an anatomical dissociation of the c-fos mRNA response to intravenous IL-1ß. Although lesions of the area postrema inhibited the IL-1 $\beta$-induced ACTH response and $c$-fos $m R N A$ response in the NTS and $\mathrm{PVH}$, these lesions did not affect the IL-1 $\beta$-induced $\mathrm{c}$-fos mRNA expression in the BST or CEA. Taken together, we propose that the c-fos mRNA expression in the BSTov and CEAl after the administration of IL-1 $\beta$ does not reflect a primary role for these nuclei in HPA axis regulation. However, it is noteworthy that the majority of ENK-, NT-, and $\mathrm{CRH}$-containing neurons of the CEA also contain glucocorticoid receptor immunoreactivity (Honkaniemi et al., 1992): Thus, these neurons probably are influenced by glucocorticoids released by I L-1 $\beta$.

Many studies have suggested that the BSTov and CEA are involved in central autonomic regulation (for review, seeSaper, 1995). The visceral nature of a systemic immune challenge suggests that the activation of these areas by IL-1 $\beta$ indeed may reflect an autonomic role. Administration of IL-1 $\beta$ results in a number of autonomic responses, such as inhibition of gastric acid secretion (Saperas et al., 1992), and the CEA in particular has been linked with this function (Henke et al., 1991). Administration of IL-1 $\beta$ also results in complex cardiovascular effects (Weinberg et al., 1988; Bataillard and Sassard, 1994), and many studies have demonstrated the roles that the BST and CEA play in cardi ovascular responses (Loewy and McKeller, 1980; I wata et al., 1987; Gelsema et al., 1989; Lewis et al., 1989; Roder and Ciriello, 1993). It is noteworthy that Fos protein expression has been demonstrated in the CEA and may be associated with various cardiovascular parameters, including hypotension with bradycardia and hypertension with tachycardia (Graham et al., 1995). Furthermore, in another model of immunechallenge, systemic administration of endotoxin at a dose that did not alter blood pressure but caused tachycardia, also elicited robust F os protein expression in the CEA (Tkacs et al., 1997). Hence, it appears that Fos may beinduced in the CEA under a variety of different cardiovascular conditions, and it would be interesting to determine whether these different conditions elicit F os in different cell types of the CEA. I n addition, administration of IL-1 $\beta$ decreases feeding, and several other anorexic agents also increase the expression of c-fos in the CEAl and BSTov, although the neurochemical phenotype is not known (Bonaz et al., 1993; Li and Rowland, 1995; Rowland et al., 1996). Indeed, we believe it is unlikely that the activation of ENK- versus $\mathrm{CRH}$-containing cells is specific 
to an immune stimulus, because preliminary data suggest that an i.p. injection of amphetamine elicits a broadly similar neurochemical pattern of c-fos mRNA distribution in these areas.

\section{Neural circuits potentially involved} in IL-1 $\beta$ activation in the BST ov and CEAI

Although projections to and from I L-1 $\beta$-activated cells of theBSTov and CEAI were not defined in the present study, it is important to think about the activated cells in terms of neural circuitry rather than in isolation. A number of elegant studies have been published that, together with the current data, suggest specific neural circuitry is engaged by i.p. IL-1 $\beta$. In terms of activational pathways, although the major afferent input to the BST is from the amygdala (Weller and Smith, 1982; Alheid et al., 1995), the GABAergic nature of the activated cells of the CEAl likely precludes this cell group from directly activating the BSTov. However, i.p. administration of IL-1 $\beta$ also results in the expression of c-fos mRNA in the medial division of the NTS and the lateral parabrachial nucleus (PBI; Brady et al., 1994; Day and Akil, 1996). The NTS projects heavily to the PB (Herbert et al., 1990) but also projects directly to both the CEA and the BST (Ricardo and Koh, 1978). Similarly, both the BSTov and the CEAI receive projections from the PBI (Bernard et al., 1993; Krukoff et al., 1993; Alden et al., 1994). Studies to lesion the PBI and NTSm or to combine neuroanatomical tracers with $\mathrm{F}$ os protein or c-fos mRNA localization may help to ascertain whether or not these nuclei are critical in the IL-1 $\beta$ activation of the BSTov and CEAI. It is noteworthy that, in addition to receiving afferents from the NTS, the $\mathrm{PBI}$ receives input from the spinal cord (Slugg and Light, 1994), and a transneuronal labeling technique has been used to demonstrate a pathway from the spinal cord to the CEA through the PB (J asmin et al., 1997). Although the involvement of spinal projections has not been demonstrated after systemic administration of IL-1 $\beta$, the possibility exists that a spinal-parabrachial pathway may be involved in the activation of the BSTov and CEAI after systemic administration of IL-1ß.

Although efferent projections from the BSTov and CEAI have been demonstrated to the PB (Moga and Gray, 1985; Moga et al., 1989), the dorsal vagal complex (Gray and Magnuson, 1987), and the midbrain central gray (Gray and Magnuson, 1992), current evidence suggests that these projections do not arise from ENK-containing neurons. Because the majority of c-fos mRNA-containing neurons in the BSTov and CEAI also contain ENK, it seems unlikely that the major projection pathway of the activated cells is back to these areas. Two el egant studies using the anterograde tracer Phaseolus vulgaris leucoagglutinin injected exclusively into subdivisions of the CEA have demonstrated a relatively discrete population of efferent projections from the CEAI (Petrovich and Swanson, 1997; J olkkonen and Pitkänen, 1998). Cells within the CEAl were shown to project intrinsically to other cells within the CEAI and CEAm in addition to projections to the BST and PB. ENK neurons of the CEAI, as discussed above, do not appear to project to the PB (Moga and Gray, 1985), but an enkephalinergic projection from the CEA to the BST has been demonstrated (Rao et al., 1987). Hence, it seems likely that the activated neurons of the CEAl observed in the present study project to the BST and/or

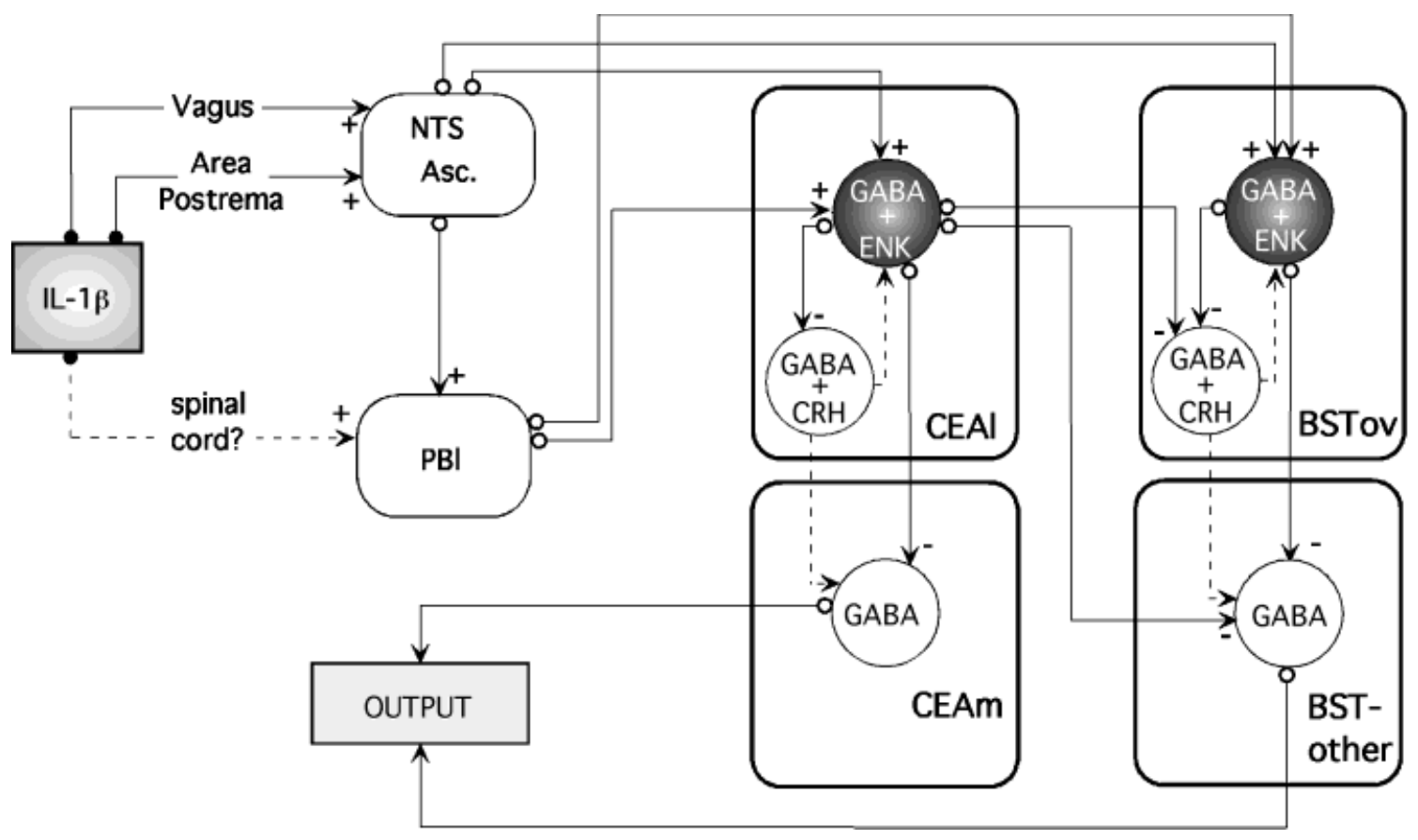

Fig. 10. Schematic diagram showing some of the pathways that may be involved in the activation of enkephalinergic neurons of the BSTov and CEAI, and some of the putative efferent projections from these neurons. It should be noted that the involvement of the spinal cord projection in activation of the parabrachial nucleus in this model is speculative at this time. In addition, although this figure highlights possible pathways involved in the c-fos mRNA response to the intraperitoneal administration of IL-1 $\beta$, it does not attempt to show all possible projections to and from the illustrated nuclei. Asc, ascending; NTS, nucleus tractus solitarius; PBI, parabrachial nucleus, lateral division; CEAm, central nucleus, Amygdala, medical devision. For other abbreviations, see Figure 1 . 
intrinsically within the $\mathrm{CEAl} / \mathrm{m}$. Given the relatively sparse activation of other regions of the BST, the medial aspect of the CEA or the CRH mRNA-containing cells in the CEAI and BSTov, it is conceivable that some or all of these cell populations are under active inhibition by the Fos-positive cells of the CEAI. The efferent projections of the BSTov are less well defined. However, there is some evidence to suggest that GABAergic cells of the BSTov project intrinsically to posterior subdivisions of the BST, whereas there does not seem to be a major GABAergic projection from the BSTov to the CEA (Sun and Cassell, 1993). Hence, our working hypothesis is that the BSTov and CEAl are activated in parallel by ascending projections from the brainstem, and the activated neurons most likely project intrinsically within the BST or CEA. It should be noted that, although the activated cell types (as determined by c-fos mRNA expression) are GABAergic, this does not imply an inhibitory output. Indeed, there is the potential for significant complexity of response, depending on the degree of activation of intrinsic GABAergic connections within and between the CEA and the BST that will have a profound impact on whether the overall output of these nuclei is inhibitory or excitatory. A simplified schematic diagram of this hypothesis indicating some of the potential connections of specific cells groups within the BSTov and CEAl is shown in Figure 10.

In summary, cells of the BSTov and the CEAI which express ENK, NT, or CRH mRNA, invariably are GABAergic. Two distinct subpopulations of GABAergic neurons exist within these areas: one containing ENK and the other containing $\mathrm{CRH}$. Both populations exhibit partial overlap with NT (Shimada et al., 1989; current study). The intraperitoneal administration of the cytokine IL-1 $\beta$ resulted in the activation of a proportionally similar population of neurochemically identified neurons in the BSTov and CEAI. All neurons in these regions that expressed c-fos mRNA were found to be GABAergic. The majority of these neurons also contained ENK mRNA, and a smaller population contained NT mRNA. However, very few neurons in the BSTov or CEAl that expressed c-fos mRNA contained $\mathrm{CRH}$ mRNA. The specificity of the response strongly suggests that discrete neural circuits may be targeted differentially within the BSTov and CEAI. In addition, the present results are consistent with the concept of an extended amygdala and demonstrate a specific coupling between the CEAI and the BSTov through the activation of distinct neurochemical subpopulations. Although the function of the activated neurons is not clear at present, it seems probable that the c-fos mRNA expression observed in the enkephalinergic cells of the CEAI and BSTov after the administration of $\mathrm{IL}-1 \beta$ reflects autonomic or somatic regulation. Identification of the efferent targets of these neurons, together with the neurochemical identification of cell populations in the BSTov and CE AI responsive to other stimuli, may help to elucidate the functional significance of their activation.

\section{ACKNOWLE DGMENTS}

The authors gratefully acknowledge the invaluable comments and advice of Dr. S. Campeau during the preparation of this article, and the technical assistance of S. Burke and J. Stewart.

\section{LITERATURE CITED}

Alden M, Besson J M, Bernard J F. 1994. Organization of the efferent projections from the pontine parabrachial area to the bed nucleus of the stria terminalis and neighboring regions: a PHA-L study in the rat. J Comp Neurol 341:289-314.

Alexander MJ , Miller MA, Dorsa DM, Bullock BP, Melloni RH, Dobner PR, Leeman SE. 1989. Distribution of NT/neuromedin N mRNA in rat forebrain: unexpected abundance in hippocampus and subiculum. Proc Natl Acad Sci USA 86:5202-5206.

Alheid GF, de Olmos J S, Beltramino CA. 1995. Amygdala and extended amygdala. In: Paxinos G, editor. The rat nervous system. San Diego: Academic Press. p 495-578.

Bataillard A, Sassard J . 1994. Cardiovascular effects of human recombinant interleukin-1 $\beta$ in conscious rats. AmJ Physiol 35:R1148-R1153.

Bernard J F, Alden M, Besson J M. 1993. The organization of the efferent projections from the pontine parabrachial area to the amygdaloid complex: a Phaseol us vulgaris leucoagglutinin (PHA-L) study in therat. J Comp Neurol 329:201-229.

Besedovsky H, Del Rey A, Sorkin E, Dinarello CA. 1986. I mmunoregulatory feedback between interleukin-1 and glucocorticoid hormones. Science 233:652-654.

Bonaz B, De Giorgio R, Tache Y. 1993. Peripheral bombesin induces c-fos protein in the rat brain. Brain Res 600:353-357.

Brady LS, Lynn AB, Herkenham M, Gottesfeld Z. 1994. Systemic interleukin-1 induces early and late patterns of c-fos mRNA expression in brain. J Neurosci 14:4951-4964.

Campeau S, Watson SJ . 1997. Neuroendocrine and behavioral response and brain pattern of c-fos induction associated with audiogenic stress. J Neuroendocrinol 9:577-588.

Campeau S, Falls WA, Cullinan WE, Helmreich DL, Davis M, Watson SJ . 1997. Elicitation and reduction of fear: behavioural and neuroendocrine indices and brain induction of the immediate-early gene c-fos. Neuroscience 78:1087-1104.

Canteras NS, Simerly RB, Swanson LW. 1994. Organization of projections from the ventromedial nucleus of the hypothalamus: a Phaseolus vulgaris-leucoagglutinin study in the rat. J Comp Neurol 1994:42-79.

Canteras NS, Simerly RB, Swanson LW. 1995. Organization of projections from the medial nucleus of the amygdala: a PHA-L study in the rat. J Comp Neurol 360:213-245.

Cassell MD, Gray TS, Kiss J Z. 1986. Neuronal architecture in the rat central nucleus of the amygdala: a cytol ogical, hodological, and immunocytochemical study. J Comp Neurol 246:478-499.

Coggeshall RE, Lekan HA. 1996. Methods for determining numbers of cells and synapses: a case for more uniform standards of review. J Comp Neurol 364:6-15.

Cullinan WE, Zaborsky L. 1991. Organization of ascending hypothalamic projections to the rostral forebrain with special reference to the innervation of cholinergic projection neurons. J Comp Neurol 306:631667.

Cullinan WE, Herman J P, Battaglia DF, Akil H, Watson SJ . 1995. Pattern and time course of immediate early gene expression in rat brain following acute stress. Neuroscience 64:477-505.

Cullinan WE, Helmreich DL, Watson SJ . 1996. Fos expression in forebrain afferents to the hypothalamic paraventricular nucleus following swim stress. J Comp Neurol 368:88-99.

Curran EJ, Watson SJ J r. 1995. Dopamine receptor mRNA expression patterns by opioid peptide cells in the nucleus accumbens of the rat: a double in situ hybridization study. J Comp Neurol 361:57-76.

Davis M. 1992. The role of the amygdala in fear and anxiety. Annu Rev Neurosci 15:353-375.

Day HEW, Akil H. 1996. Differential pattern of c-fos mRNA in rat brain following central and systemic administration of interleukin-1-beta: implications for mechanism of action. Neuroendocrinology 63:207-218.

Day HEW, Curran EJ , Watson SJ , Akil H. 1996. Co-expression of enkephalin and GABA in neurons of the rat central nucleus of the amygdala responsive to interleukin-1 $\beta$. Society for Neuroscience Meeting: Washington, DC. Soc Neurosci Abstr 43.4.

Dunn J D. 1987. Plasma corticosterone responses to electrical stimulation of the bed nucleus of the stria terminalis. Brain Res 407:327-331.

Ericsson A, Kovacs KJ, Sawchenko PE. 1994. A functional anatomical analysis of central pathways subserving the effects of interleukin-1 on stress-related neuroendocrine neurons. J Neurosci 14:897-913.

Esclapez M, Tillakaratne NJ K, Kaufman DL, Tobin AJ , Houser CR. 1994. Comparative localization of two forms of glutamic acid decarboxylase 
and their mRNAs in rat brain supports the concept of functional differences between the forms. J Neurosci 14:1834-1855.

Fleshner M, Goehler LE, Hermann J, Relton J K, Maier SF, Watkins LR. 1995. Interleukin-1 $\beta$ induced corticosterone elevation and hypothalamic NE depletion is vagally mediated. Brain Res Bull 37:605-610.

Gallagher M, Chiba AA. 1996. The amygdala and emotion. Curr Opin Neurobiol 6:221-227.

Gelsema AJ , Agarwal SK, Calaresu FR. 1989. Cardiovascular responses and changes in neural activity in the rostral ventrolateral medulla elicited by electrical stimulation of the amygdala of the rat. J Auton Nerv Syst 27:91-100.

Graham J C, Hoffman GE, Sved AF. 1995. c-Fos expression in brain in response to hypotension and hypertension in conscious rats. J Auton Nerv Syst 55:92-104.

Gray TS, Magnuson DJ . 1987. Neuropeptide neuronal efferents from the bed nucleus of the stria terminalis and central amygdaloid nucleus to the dorsal vagal complex in the rat. J Comp Neurol 262:365-374.

Gray TS, Magnuson DJ . 1992. Peptide immunoreactive neurons in the amygdala and the bed nucleus of the stria terminalis project to the midbrain central gray in the rat. Peptides 13:451-460.

Gray TS, Carney ME, Magnuson DJ . 1989. Direct projections from the central amygdaloid nucleus to the hypothalamic paraventricular nucleus: possible role in stress-induced adrenocorticotropin release. Neuroendocrinol ogy 50:433-446.

Gray TS, Piechowski RA, Yracheta J M, Bethea CL, Van de Kar LD. 1993. I botenic acid lesions in the bed nucleus of thestria terminalis attenuate conditioned stress-induced increases in prolactin, ACTH and corticosterone. Neuroendocrinol ogy 57:517-524.

Harlan RE, Shivers BD, Romano GJ, Howells RD, Pfaff DW. 1987 Localization of preproenkephalin mRNA in the rat brain and spinal cord by in situ hybridization. J Comp Neurol 258:159-184.

Hauptmann G, Gerster T. 1994. Two colour whole-mount in situ hybridization to vertebrate and Drosophila embryos. Trends Genet 10:266.

Henke PG, Ray A, Sullivan RM. 1991. The amygdala. Emotions and gut functions. Digest Dis Sci 36:1633-1643.

Herbert H, Moga MM, Saper CB. 1990. Connections of the parabrachial nucleus with the nucleus of the solitary tract and the medullary reticular formation in the rat. J Comp Neurol 293:540-580.

Honkaniemi J , Pelto-Huikko M, Rechardt L, Lammi A, Fuxe K, Gustafsson J-A, Wikstrom A-C, Hökfelt T. 1992. Colocalization of peptide and glucocorticoid receptor immunoreactivities in rat central amygdaloid nucleus. Neuroendocrinology 55:451-459.

Hurley KM, Herbert H, Moga MM, Saper CB. 1991. Efferent projections of the infralimbic cortex of the rat. J Comp Neurol 308:249-276.

I wata J, Chida K, LeDoux J E. 1987. Cardiovascular responses elicited by stimulation of neurons in the central amygdaloid nucleus in awake but not anesthetized rats resemble conditioned emotional responses. Brain Res 418:183-188.

J asmin L, Burkey AR, Card J P, Basbaum AI. 1997. Transneuronal labeling of a nociceptive pathway, the spino-(trigemino-)parabrachio-amygdaloid, in the rat. J Neurosci 17:3751-3765.

J ia H-G, Rao Z-R, Shi J -W. 1997. Evidence of $\gamma$-aminobutyric acidergic control over the catecholaminergic projection from the medulla oblongata to the central nucleus of the amygdala. J Comp Neurol 381:262281.

J olkkonen E, Pitkänen A. 1998. Intrinsic connections of the rat amygdaloid complex: projections originating in the central nucleus. J Comp Neuro 395:53-72.

J u G, Swanson LW. 1989. Studies on the cellular architecture of the bed nucleus of the stria terminalis in the rat: I. Cytoarchitecture. J Comp Neurol 280:587-602.

J u G, Swanson LW, Simerly RB. 1989. Studies on the cellular architecture of the bed nuclei of the stria terminalis in the rat: II. Chemoarchitecture. J Comp Neurol 280:603-621.

Kapcala LP, He J R, GaoY, Pieper J O, DeTolla LJ . 1996. Subdiaphragmatic vagotomy inhibits intra-abdominal interleukin-1 $\beta$ stimulation of adre nocorticotropin secretion. Brain Res 728:247-254.

Krukoff TL, Harris KH, J hamandas J H. 1993. Efferent projections from the parabrachial nucleus demonstrated with theanterogradetracer Phaseolus vulgaris leucoagglutinin. Brain Res Bull 30:163-172.

Lee HY, Whiteside MB, Herkenham M. 1998. Area postrema removal abolishes stimulatory effects of intravenous interleukin-1 $\beta$ on hypothalamic-pituitary-adrenal axis activity and c-fos mRNA in the hypothalamic paraventricular nucleus. Brain Res Bull 46:495-503.

Lewis SJ , VerberneAJ , Robinson TG, J arrott B, Louis WJ , Beart PM. 1989.
Excitotoxin-induced lesions of the central but not basolateral nucleus of the amygdala modulate the baroreceptor heart rate reflex in conscious rats. Brain Res 494:232-240.

Li BH, Rowland NE. 1995. Effects of vagotomy on cholecystokinin- and dexfenfluramine-induced Fos-like immunoreactivity in the rat brain. Brain Res Bull 37:589-593.

Loewy AD, McKeller S. 1980. The neuroanatomical basis of central cardiovascular control. FASEB J 39:2495-2503.

MakinoS, Gold PW, Schulkin J . 1994. Corticosterone effects on corticotropinreleasing hormone mRNA in the central nucleus of the amygdala and the parvocellular region of the paraventricular nucleus of the hypothalamus. Brain Res 640:105-112.

Maren S, Fansel ow MS. 1996. The amygdala and fear conditioning: has the nut been cracked? Neuron 16:237-240.

Matta SG, Valentine J D, Sharp BM. 1997. Nicotinic activation of CRH neurons in extrahypothalamic regions of the rat brain. Endocrine 7:245-253.

McDonald AJ , Mascagni F. 1997. Projections of the lateral entorhinal cortex to the amygdala: A Phaseol us vul garis-leucoagglutinin study in the rat. Neuroscience 77:445-459.

Moga MM, Gray TS. 1985. Evidence for corticotropin-releasing factor, NT, and somatostatin in the neural pathway from the central nucleus of the amygdala to the parabrachial nucleus. J Comp Neurol 241:275-284.

Moga MM, Saper CB, Gray TS. 1989. Bed nucleus of the stria terminalis: cytoarchitecture, immunohistochemistry, and projection to the parabrachial nucleus in the rat. J Comp Neurol 283:315-332.

Moga MM, Weis RP, Moore RY. 1995. Efferent projections of the paraventricular thalamic nucleus in the rat. J Comp Neurol 359:221-238.

Oertel WH, Riethmuller G, Mugnaini E, Schmechel DE, Weindl A, Gramsch C, Herz A. 1983. Opioid peptide-like immunoreactivity localized in GABAergic neurons of rat neostriatum and central amygdal oid nucleus. Life Sci 1:73-76.

Petrovich GD, Swanson LW. 1997. Projections from the lateral part of the central amygdalar nucleus to the postulated fear conditioning circuit. Brain Res 763:247-254.

Pickel VM, Van Bockstaele EJ, Chan J, Cestari DM. 1995. Amygdala efferents form inhibitory-type synapses with a subpopulation of catecholaminergic neurons in the rat nucleus tractus solitarius. J Comp Neurol 362:510-523.

Prewitt CMF, Herman JP. 1998. Anatomical interactions between the central amygdalaoid nucleus and the hypothalamic paraventricular nucleus of the rat: a dual tract-tracing analysis. J Chem Neuroanat 15:173-185.

Rao ZR, Yamano M, Shiosaka S, Shinohara A, Tohyama M. 1987. Origin of leucine-enkephalin fibers and their two main afferent pathways in the bed nucleus of the stria terminalis in the rat. Exp Brain Res 65:411420

Ricardo J A, Koh ET. 1978. Anatomical evidence of direct projections from the nucleus of the solitary tract to the hypothalamus, amygdala, and other forebrain structures in the rat. Brain Res 153:1-26.

Roder S, CirielloJ . 1993. Contribution of bed nucleus of the stria terminalis to the cardiovascular responses elicited by stimulation of the amygdala. J Auton Nerv Syst 45:61-75.

Rowland NE, Bellinger LL, Li BH, Mendel VE. 1996. Satietin: F os mapping of putative brain sites of action. Brain Res 717:189-192.

Saper CB. 1995. Central autonomic system. In: Paxinos G, editor: The rat nervous system. San Diego: Academic Press. p 107-135.

Saper CB. 1996. Any way you cut it: a new journal policy for the use of unbiased counting methods. J Comp Neurol 364:5.

Saperas ES, Cominelli F, Tache Y. 1992. Potent inhibition of gastric acid secretion by intravenous interleukin-1 $1 \beta$ and $-\alpha$ in rats. Peptides 13:221226.

Savander V, Go C-G, LeDoux J E, Pitkänen A. 1995. Intrinsic connections of the rat amygdaloid complex: projections originating in the basal nucleus. I Comp Neurol 361:345-368.

Savander V, Go C-G, LeDoux J E, Pitkänen A. 1996. Intrinsic connections of the rat amygdaloid complex: projections originating in the accessory basal nucleus. J Comp Neurol 374:291-313.

Shimada S, Inagaki S, Kubota Y, Ogawa N, Shibasaki T, Takagi H. 1989. Coexistence of peptides (corticotropin releasing factor/NT and substance $\mathrm{P} /$ somatostatin) in the bed nucleus of the stria terminalis and central amygdal oid nucleus of the rat. Neuroscience 30:377-383.

Slugg RM, Light AR. 1994. Spinal cord and trigeminal projections to the pontine parabrachial region in the rat as demonstrated with Phaseol us vulgaris leucoagglutinin. J Comp Neurol 339:49-61. 
Sun N, Cassell MD. 1993. Intrinsic GABAergic neurons in the rat central extended amygdala.J Comp Neurol 330:381-404.

Sun N, Roberts L, Cassell MD. 1991. Rat central amygdaloid nucleus projections to the bed nucleus of the stria terminalis. Brain Res Bull 27:651-662.

Sun N, Yi H, Cassell MD. 1994. Evidence for a GABAergic interface between cortical afferents and brainstem projection neurons in the rat central extended amygdala. J Comp Neurol 340:43-64.

Swanson LW. 1992. Brain maps: structure of the rat brain. Amsterdam: Elsevier.

Swanson LW, Petrovich GD. 1998. What is the amygdala? Trends Neurosci 21:323-331.

Tkacs NC, Li J , Strack AM. 1997. Central amygdala F os expression during hypotensive or febrile, nonhypotensive endotoxemia in conscious rats. J Comp Neurol 379:592-602.

Veening J G, van der Meer MJ M, J oosten H, HermusARMM, Rijnkels CEM, Geeraedts LM, Sweep CGJ . 1993. Intravenous administration of interleukin-1 $\beta$ induces F os-like immunoreactivity in corticotropin-releasing hormone neurons in the paraventricular hypothalamic nucleus of the rat. J Chem Neuroanat. 6:391-397.

Veinante $P$, Stoeckel M-E, Freund-Mercier M-J . 1997. GABA- and peptideimmunoreactivities co-localize in the rat central extended amygdala. Neuroreport 8:2985-2989.

Vertes RP, Crane AM, Colom LV, Bland BH. 1995. Ascending projections of the posterior nucleus of the hypothalamus: PHA-L analysis in the rat. J Comp Neurol 359:90-116.

Watkins LR, Goehler LE, Relton J K, Tartaglia N, Silbert L, Martin D, Maier SF. 1995. Blockade of interleukin-1 induced hyperthermia by subdiaphragmatic vagotomy: evidence for vagal mediation of immune brain communication. Neurosci Lett 183:27-31.

Weinberg J R, Wright DJ , Guz A. 1988. Interleukin-1 and tumour necrosis factor cause hypotension in the conscious rabbit. Clin Sci 75:251-255.

Weller KL, Smith DA. 1982. Afferent connections to the bed nucleus of the stria terminalis. Brain Res 232:255-270.

Wray S, H offman GE. 1983. Organization and interrelationship of neuropeptides in the central amygdaloid nucleus of the rat. Peptides 4:525-541. 